\title{
CLOSURE REPORT FOR CAU NO. 400: BOMBLET PIT AND FIVE POINTS LANDFILL, TONOPAH TEST RANGE
}

DOE Nevada Operations Office

Las Vegas, Nevada

Controlled Copy No.:

Revision: 0

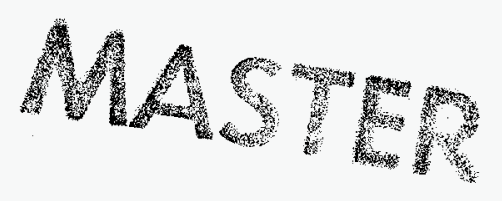

November 1996

DISTRISUTION OF THIS DOCUMENT IS UAMRTED 


\section{DISCLAIMER}

Portions of this document may be illegible in electronic image products. Images are produced from the best available original document. 


\section{CLOSURE REPORT FOR CAU NO. 400: BOMBLET PIT AND FIVE POINTS LANDFILL, TONOPAH TEST RANGE}
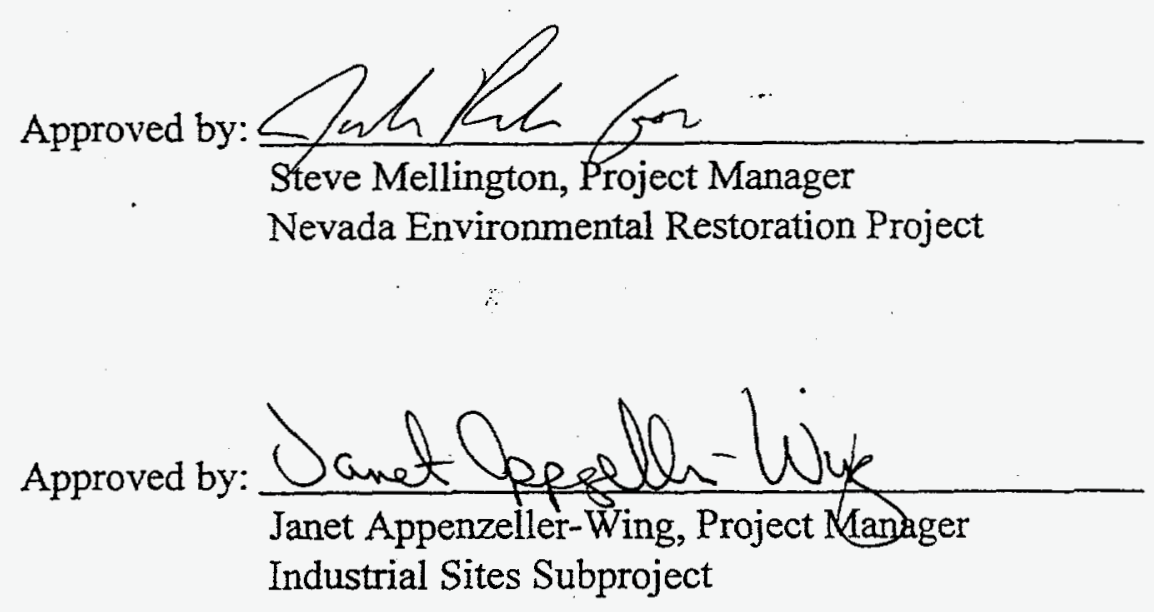

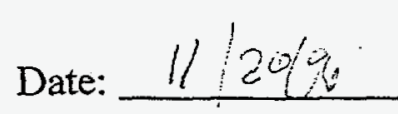

Date: 


\section{Table of Contents}

List of Figures

iii

List of Tables iv

List of Acronyms and Abbreviations .$v$

Executive Summary vii

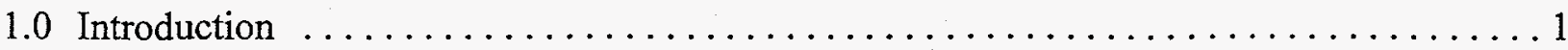

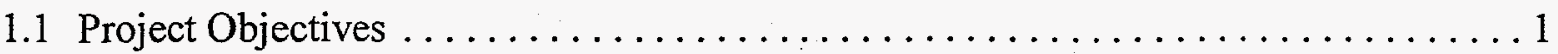

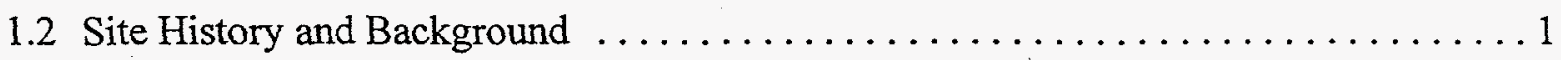

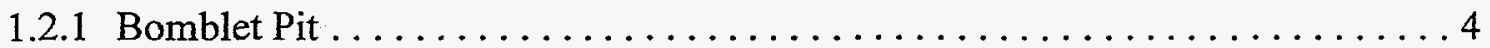

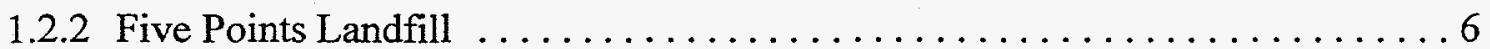

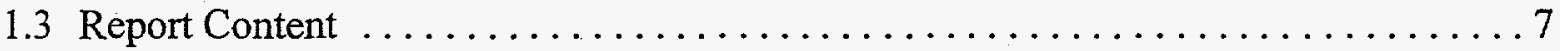

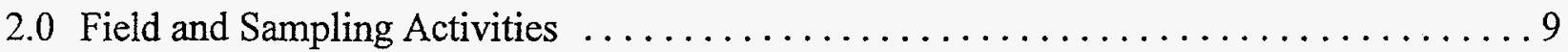

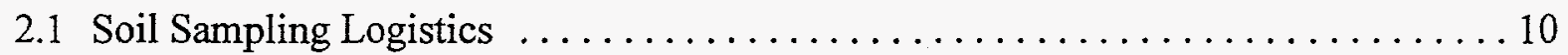

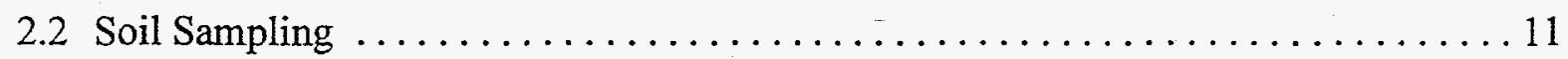

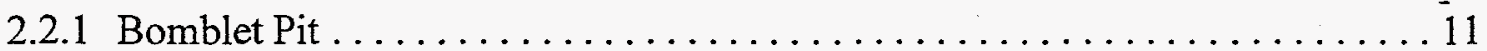

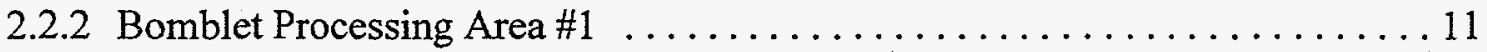

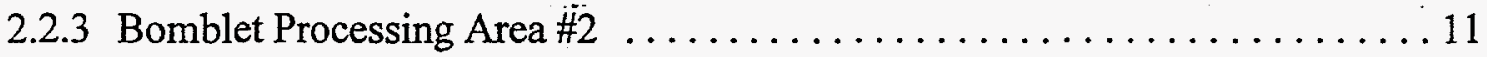

2.2.4 Large UXO Processing and Scrap Storage Area .............. 14

2.2 .5 Stockpile $\# 1$. . . . . . . . . . . . . . . . . . . . . . . . . . . . 14

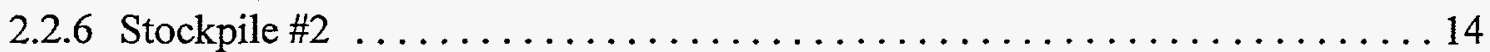

2.2.7 Bomblet Pit Background Sample Area ................ 14

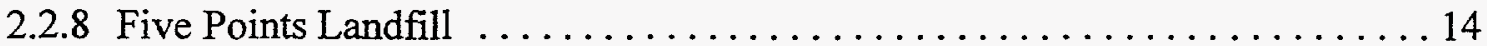

2.2.9 Five Points Landfill Background Sample Area $\ldots \ldots \ldots \ldots \ldots \ldots \ldots \ldots$

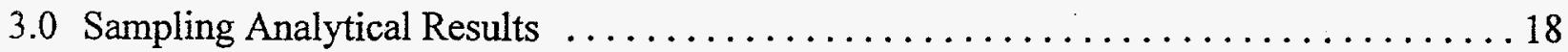

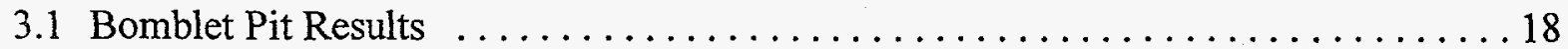

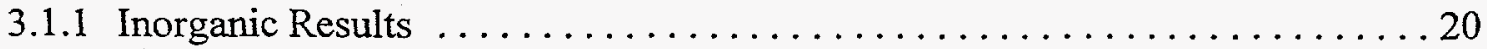




\section{Table of Contents (Continued)}

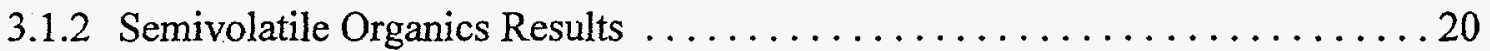

3.1.3 Nitroaromatics and Nitramines Results $\ldots \ldots \ldots \ldots \ldots \ldots \ldots \ldots \ldots$

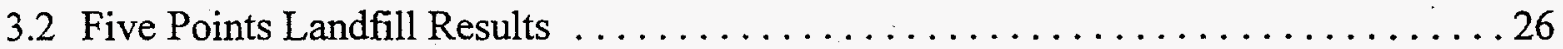

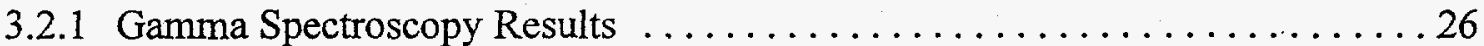

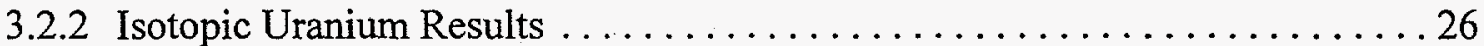

3.2 .3 Isotopic Plutonium Results . . . . . . . . . . . . . . . . . . . 28

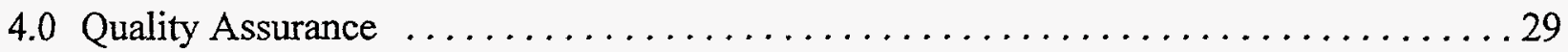

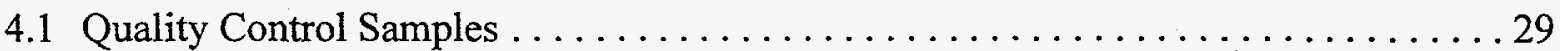

4.1 .1 Field Quality Control Samples .......................... 29

4.1.2 Laboratory Quality Control Samples $\ldots \ldots \ldots \ldots \ldots \ldots \ldots \ldots \ldots \ldots \ldots \ldots \ldots$

4.2 Quality Assurance Objectives Measurements ...................... 31

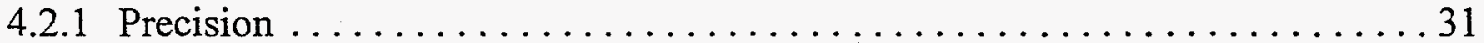

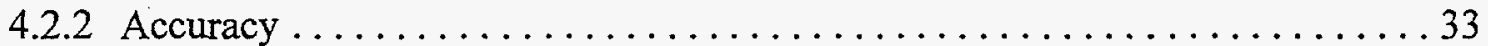

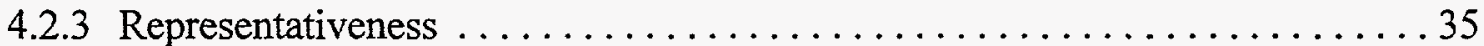

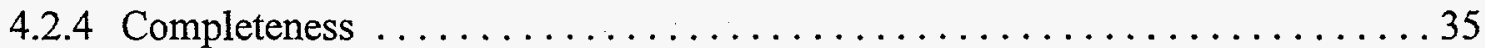

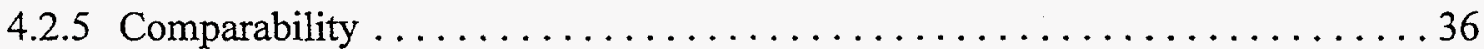

4.3 Field Deficiencies/Nonconformance ............................. 36

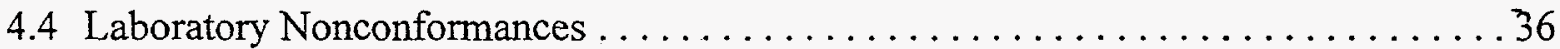

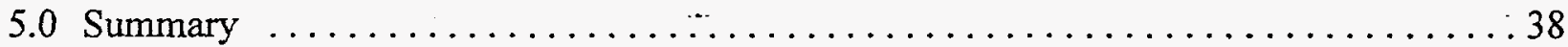

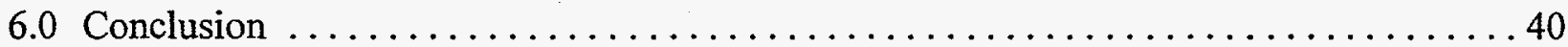

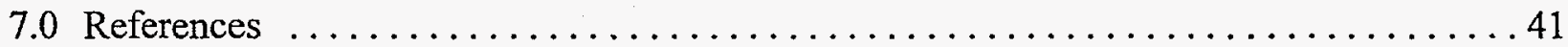

Appendix A - U-238 Concentration in Soil at the Five Points Landfill, Tonopah Test Range . . 43

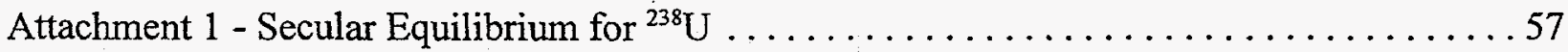




\section{List of Figures}

1-1 Location Map, Tonopah Test Range $\ldots \ldots \ldots \ldots \ldots \ldots \ldots \ldots \ldots \ldots \ldots \ldots \ldots \ldots \ldots$

1-2 Site Layout, Tonopah Test Range $\ldots \ldots \ldots \ldots \ldots \ldots \ldots \ldots \ldots \ldots \ldots \ldots \ldots \ldots \ldots \ldots$

1-3 Site Location Map, Bomblet Pit, Tonopah Test Range $\ldots \ldots \ldots \ldots \ldots \ldots$

1-4 Site Location Map, Five Points Landfill, Tonopah Test Range $\ldots \ldots \ldots \ldots \ldots 8$

2-1 Sample Location Map, Bomblet Pit, Tonopah Test Range $\ldots \ldots \ldots \ldots \ldots \ldots$

2-2 Sample Location Map, Bomblet Pit, Processing Areas \#1 and \#2,

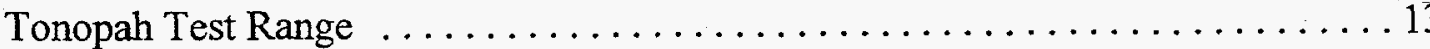

2-3 Sample Location Map, Large UXO Processing Area, Bomblet Pit, Tonopah Test Range ................................... 15

2-4 Sample Location Map, Background Surface-Soil Collection Area,

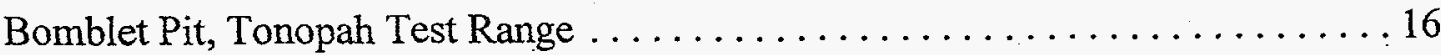

2-5 Sample Location Map, Five Points Landfill and Background Collection Area, Tonopah Test Range ................................ 17 


\section{List of Tables}

Number

3-1 Suspected Constituents of Concern and Closure Standards

3-2 Summary of TCLP Metals Analytical Results for Soil Samples Collected from the Bomblet Pit

3-3 Summary of TCLP Semivolatile Organics Analytical Results for Soil Samples Collected from the Bomblet Pit

3-4 Summary of Nitroaromatics and Nitroamines Analytical Results for Soil Samples Collected from the Bomblet Pit

3-5 Summary of Radiological Gamma Spectroscopy Results for

Soil Samples Collected from the Five Points Landfill

3-6 Summary of Radiological (Isotopic) Results for Soil Samples Collected from the Five Points Landfill 28

4-1 Bomblet Pit and Five Points Landfill Quality Control Samples

Collected for Laboratory Analysis

4-2 Analytical Methods Used for Analysis of Quality Control Samples

4-3 Laboratory Precision Measurements for Bomblet Pit and Five Points Landfill Surface Soil Sampling Data

4-4 Laboratory Accuracy Measurements for Bomblet Pit and Five Points Landfill Surface Soil Sampling Data 


\section{List of Acronyms and Abbreviations}

CAS Corrective Action Site(s)

CAU Corrective Action Unit(s)

CFR Code of Federal Regulations

CLP Contract Laboratory Program

$\mathrm{cm} \quad$ Centimeter(s)

COC Constituent(s) of concern

CRDL Contract-required detection limit(s)

DOE U.S. Department of Energy

DOE/NV U.S. Department of Energy, Nevada Operations Office

DQO Data Quality Objective(s)

DU Depleted uranium

EPA U.S. Environmental Protection Agency

$\mathrm{ft} \quad$ Foot (feet)

$\mathrm{ft}^{3} \quad$ Cubic foot (feet)

HMX Octahydro-1,3,5,7-tetranitro-1,3,5,7-tetrazocine

in. Inch(es)

$\mathrm{km} \quad$ Kilometer(s)

$\mathrm{km}^{2} \quad$ Square kilometer(s)

Ib Pound(s)

IT IT Corporation

m Meter(s)

$\mathrm{m}^{3} \quad$ Cubic meter(s)

$\mathrm{mg} / \mathrm{kg} \quad$ Milligram(s) per kilogram

$\mathrm{mg} / \mathrm{L} \quad$ Milligram(s) per liter

$\mathrm{mi} \quad \mathrm{Mile}(\mathrm{s})$

$\mathrm{mi}^{2} \quad$ Square mile(s)

MDA Minimum detectable activity level(s)

MS/MSD Matrix spike/matrix spike duplicate(s)

NA Not applicable

ND Not detected

NDEP Nevada Division of Environmental Protection 


\section{List of Acronyms and Abbreviations (Continued)}

NTS Nevada Test Site

$\mathrm{pCi} / \mathrm{g} \quad$ PicoCurie(s) per gram

QA Quality assurance

QAPP Quality Assurance Project Plan

QC Quality control

RCRA Resource Conservation and Recovery Act

RDX 1,3,5-trinitro-1,3,5-triazine

RPD Relative percent difference

SAFER Streamlined Approach for Environmental Restoration

SNL Sandia National Laboratories

SVOC Semivolatile organic compound(s)

TC

Toxicity characteristic

TCLP

Toxicity Characteristic Leaching Procedure

TTR

Tonopah Test Range

UXO Unexploded ordnance

VCA Voluntary Corrective Action

$\% \mathrm{R} \quad$ Percent recovery 


\section{Executive Summary}

From January 1995 to June 1995, cleanup activities were performed at five ordnance disposal sites located on the Tonopah Test Range (TTR). The Bomblet Pit and Five Points Landfill, included in Corrective Action Unit (CAU) No. 400, were two of these five sites, and the cleanup activities were conducted as part of a Voluntary Corrective Action (VCA) performed by the U.S. Department of Energy, Nevada Operations Office (DOENV). After the signing of the Federal Facility Agreement Consent Order in May 1996, the VCA activities later became part of a streamlined approach for site closure conducted under the Streamlined Approach for Environmental Restoration (SAFER) concept. The SAFER process is employed at CAUs where enough information exists about the nature and extent of contamination to propose an appropriate corrective action prior to the implementation of a Corrective Action Investigation. Activities conducted at the Bomblet Pit and Five Points Landfill were performed for the proposed clean closure of the two sites.

The Bomblet Pit and the Five Points Landfill have been designated as Corrective Action Sites (CASs), and verification samples were collected at the two sites in June 1996 as part of the SAFER process. Samples from the Bomblet Pit (CAS No. TA-55-001-TAB2) were analyzed for Toxicity Characteristic Leaching Procedure (TCLP) metals, TCLP semivolatile organics, and total nitroaromatics and nitroamines. Samples collected from the Five Points Landfill (CAS No. TA-19-001-05PT) were analyzed for gamma spectroscopy, isotopic uranium, and isotopic plutonium.

All work was performed in accordance with the Voluntary Correction Action Work Plan for Ordnance Removal from Five Disposal Pits at the Tonopah Test Range (DOE, 1995); the Streamlined Approach for Environmental Restoration Plan, Corrective Action Unit No. 400: Bomblet Pit and Five Points Landfill, Tonopah Test Range (DOE, 1996) (the SAFER Plan); the Field Sampling Instructions for Soil Sampling and Remediation activities at the Bomblet Pit and Five Points Landfill, Tonopah Test Range (IT, 1996); and approved procedures, with noted nonconformances. These nonconformances are not significant quality control deficiencies for the project. Evaluation of the project quality assurance objectives indicates that the objectives were met. A portion of the analytical data were validated using U.S. Environmental Protection Agency (EPA) approved procedures (for Contract Laboratory Program [CLP] analyses). 
Analytical results for samples collected from the Bomblet Pit indicate the following:

- Cadmium concentrations were detected above contract-required detection limits (CRDLs) in samples collected from Stockpiles \#1 and \#2, the Bomblet Pit, and the Bomblet Processing Area \#2. The concentrations do not exceed the closure standard for cadmium.

- One sample from the Large Unexploded Ordnance Processing and Scrap Storage Area detected lead above the CRDL limit; however, this concentration does not exceed the closure standard for lead.

- No other TCLP metals were detected in the samples above CRDLs.

- Semivolatile organics were not detected above CRDLs in any of the samples collected

- from the Bomblet Pit site.

- Concentrations of hexahydro-1,3,5-trinitro-1,3,5-triazine (RDX) were detected above CRDLs; however, the concentrations do not exceed the closure standard. RDX is a main constituent of the explosives used during VCA activities.

Radiological results for samples collected from the Five Points Landfill indicate the following:

- Almost all radionuclide concentrations from the samples collected from within the landfill are at or below background concentrations.

- Isotopic uranium results were deemed unusable because of low recovery of tracers (matrix spikes) in soil samples. The chemical yield of the uranium tracer in the quality control samples were within the target range. Nevertheless, due to the low recovery of the uranium spike in the soil sample, it was considered prudent to evaluate an alternative method for determining the isotopic uranium concentration in the soil samples. Although uranium-238 is not a gamma emitter, several of its decay products are gamma emitters. By performing calculations on the gamma spectroscopy results, it was possible to determine a range in which the concentrations of uranium- 238 may be found in the soil at the Five Points Landfill. The most probable concentration for uranium-238 in the soil at the Five Points Landfill is in the range of 1.1 to 4.4 picoCuries per gram (pCi/g). This concentration is typical of background concentrations in soils found on and in the vicinity of the Nevada Test Site. The maximum probable uranium- 238 concentration ranged from 7.2 to $18.7 \mathrm{pCi} / \mathrm{g}$. The probability that the uranium -238 concentration exceeds $18.7 \mathrm{pCi} / \mathrm{g}$ is less than 1 in $1,000,000$, or less than $10^{-6}$. The range of uranium-238 concentration in soil is orders of magnitude less than the guideline concentration of $500 \mathrm{pCi} / \mathrm{g}$. 
Page ix of ix

The results demonstrate that the environmental remediation activities at the Five Points Landfill were successful in removing the uranium-238 contamination.

- Anomalous plutonium-239/240 concentrations were detected in one site characterization sample from the Five Points Landfill (Sample No. TTR00072) and one background sample (No. TTR00065) collected from the Five Points Landfill Background Sample Area. The plutonium-239/240 concentrations were anomalously higher than the other samples from the landfill and the background sample area, but still well below concentrations from background samples collected from other areas on the Nevada Test Site and TTR.

- All other sample results for isotopic plutonium were not significantly different than background levels.

EPA Equation 8, a statistical method found in Chapter 9 of EPA's SW-846, Test Methods for Evaluating Solid Waste, Physical/Chemical Methods (EPA, 1992), was applied to all parameters detected above the CRDLs. It was determined that the number of samples collected was in excess of that required to obtain the required upper confidence limit of 90 percent. This meant that the appropriate number of samples were collected and analyzed to accurately verify that constituents of concern (COC) were not present above closure standards.

Based on these findings, it should be possible to achieve clean closure of both sites, according to the Nevada Division of Environmental Protection (NDEP) regulations, without further assessments. Upon notice of completion from NDEP, the sites will be restored and revegetated as specified in Section 3.7 of the SAFER Plan (DOE, 1996). 


\subsection{Introduction}

This Closure Reports presents the information obtained from corrective and investigative actions performed to affirm the decision for clean closure of Corrective Action Unit No. 400 which includes the Bomblet Pit and the Five Points Landfill, two sites used for disposal of unexploded ordnance (UXO) and other solid waste at the U.S. Department of Energy's (DOE) Tonopah Test Range, located in south-central Nevada (Figures 1-1 and 1-2). The first phase, or corrective action, for clean closure was performed under the Voluntary Correction Action Work Plan for Ordnance Removal from Five Disposal Sites at the Tonopah Test Range (DOE, 1995), hereafter referred to as the VCA Work Plan. The second phase consisted of collecting verification samples under the Streamlined Approach for Environmental Restoration Plan, CAUNo. 400: Bomblet Pit and Five Points Landfill, Tonopah Test Range (DOE, 1996), hereafter referred to as the SAFER Plan. Results of the two phases are summarized in this document.

\subsection{Project Objectives}

The objectives of this project were to complete the following:

- Remove and properly dispose of UXO and other solid waste located within the two CASs.

- Verify adequacy, correctness, and completeness of process knowledge through sampling and analysis.

- Verify that additional soil excavation and remediation are not required and that clean closure can be obtained.

- Characterize soil excavated during corrective actions performed as part of the VCA.

\subsection{Site History and Background}

The TTR occupies about 1,616 square kilometers $\left(\mathrm{km}^{2}\right)\left(624\right.$ square miles [ $\left.\left.\mathrm{mi}^{2}\right]\right)$. It is bordered on the south, east, and west by the Nellis Air Force Range and on the north by sparsely populated public land administered by the U.S. Bureau of Land Management and the U.S. Forest Service.

Since 1957, the TTR has been operated for the DOE by Sandia National Laboratories (SNL) and used for weapons test-support activities varying from simple tests of hardware components or 
Date: $11 / 22 / 96$

Page 2 of 58
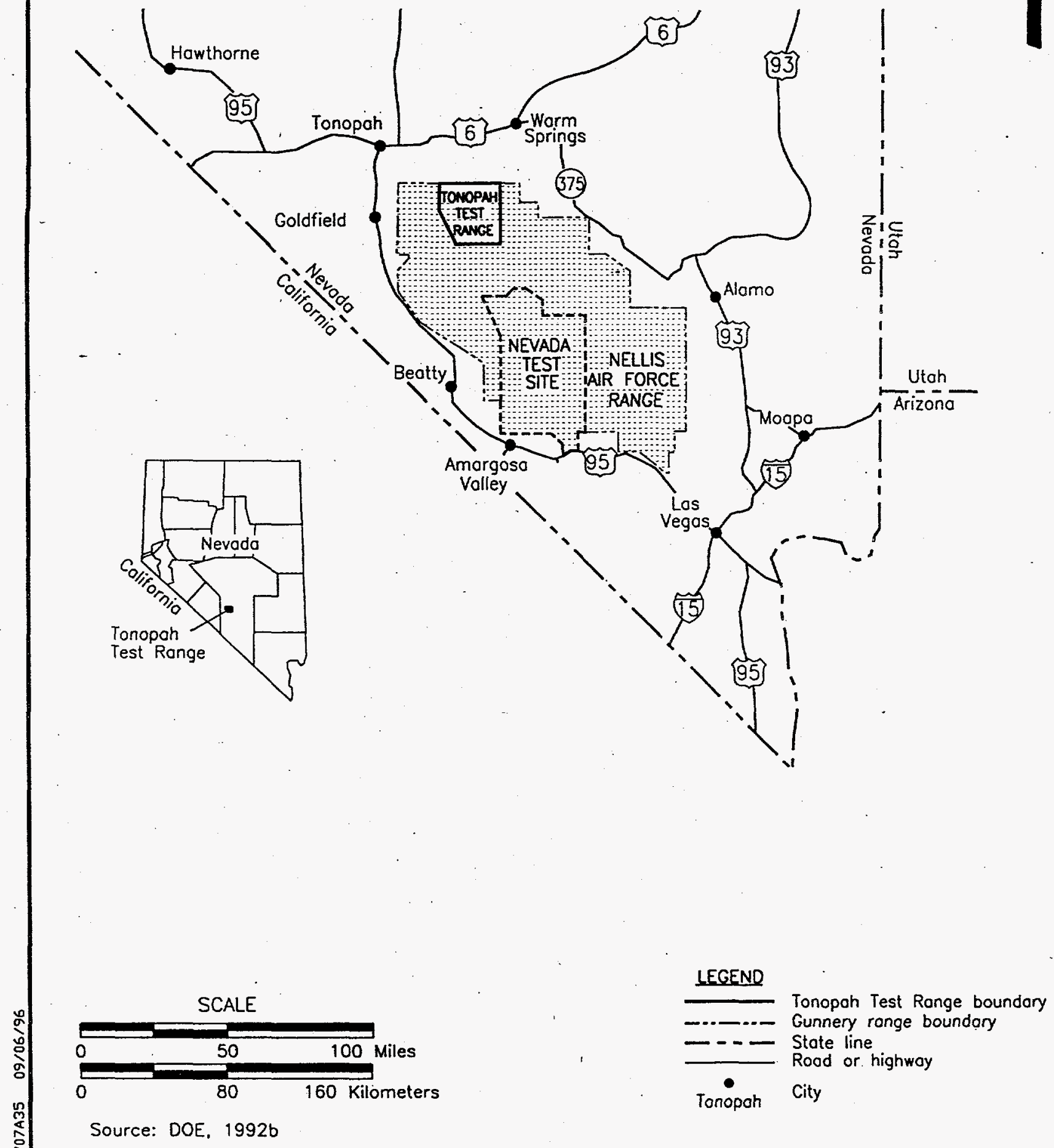

Figure 1-1

Location Map, Tonopah Test Range 


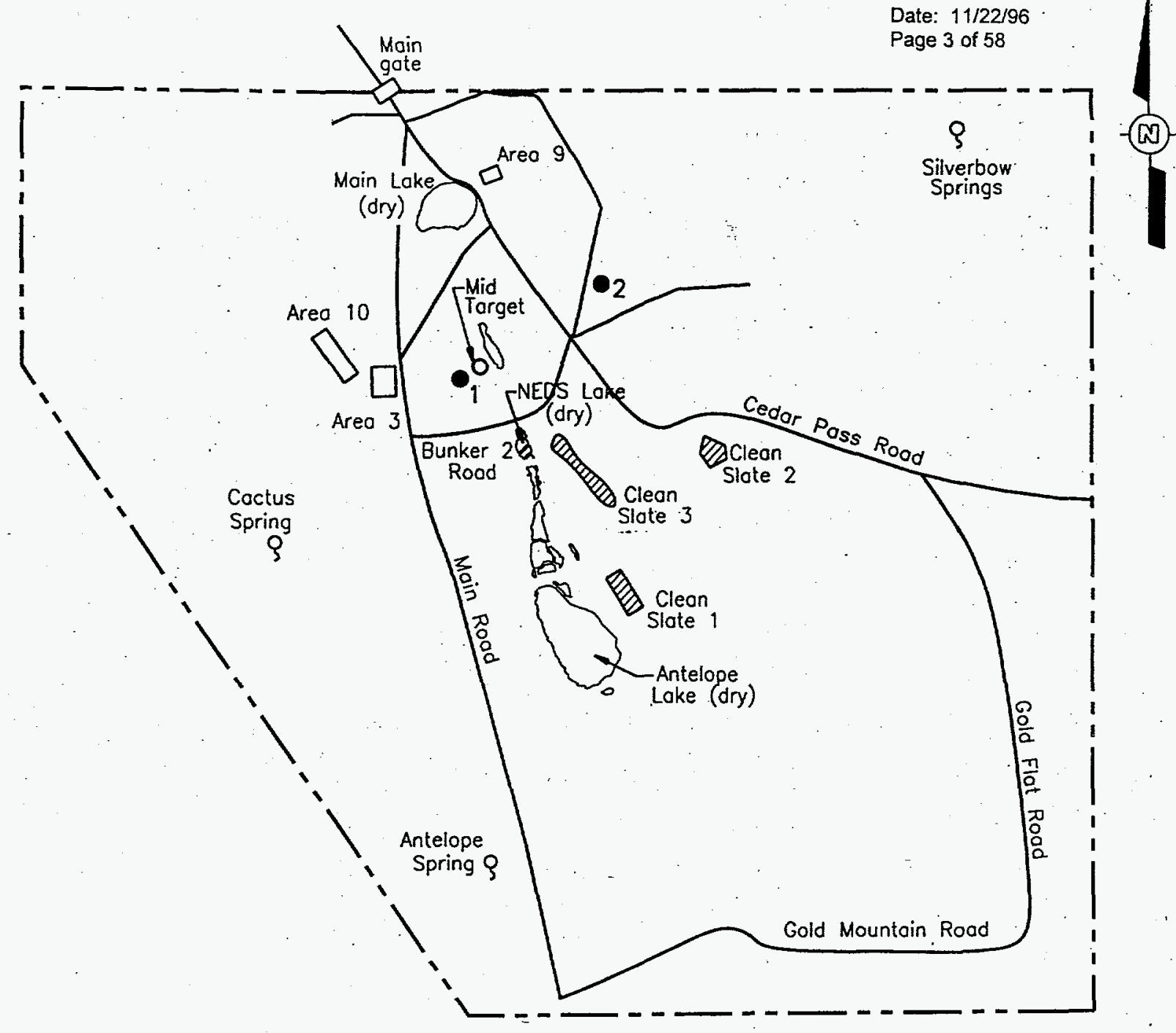

LEGEND

SCALE

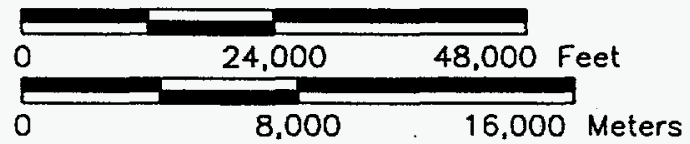

_ - - Tonopah Test Range boundary - Primory roodway

EDeration Roller Cooster sites

$\square$ Area/gote

९. Spring

1 Bomblet Pit

2 Five Points Landfill

Figure 1-2

Site Layout, Tonopah Test Range 
systems needing limited support to rocket launches or air drops of test vehicles requiring full range support for the U.S. Air Force, Army, and Navy operational and test groups as well as some defense contractors (DOE, 1996).

The TTR is divided into several functional and administrative areas (Figure 1-2). Areas 3 and 9 and a Test Area along the flight line are under Sandia National Laboratories (SNL) control; Areas 3 and 9 are the main centers of SNL activities. Area 3 is also known as the Control Point Area and includes support facilities for maintenance and operations. Areas 9 is the center for rocket and gun firings, with impact areas to the southeast, as well as ordnance storage and related test support operations. The Test Area is a series of dry lakes that begin at Main Lake near Area 9, continue south for about 21 kilometers (km) (13 miles [mi]), and end with Antelope Lake. Area 10 and other remote parts of the range are under the control of the U.S. Air Force.

\subsubsection{Bomblet Pit}

The Bomblet Pit is located approximately one mile northwest of Bunker 2 Road, as shown in Figures 1-2 and 1-3. The Bomblet Pit and five associated excavations were used for the disposal of debris from antipersonnel and antivehicular bomblet (or cluster bomb unit) tests that were conducted between the north end of Antelope Lake and Mid-Target (Figure 1-2) during the 1970s (DOE, 1995).

As part of the VCA Work Plan activities performed from January 1995 to June 1995, all UXO and debris were removed from the Bomblet Pit, and all geophysical anomalies were excavated and removed. The pit and four of the five associated excavations were found to contain approximately 22,000 bomblets; bomblet dispenser clamshell sections; one guidance section; two spent rocket motors; four unfuzed, inert MK84 2,000-pound (lb) bombs; two unfuzed, inert MK82 500-lb bombs; and other assorted debris. Nothing was found in the fifth excavation.

There were three processing areas established and used in conjunction with the UXO removal activities at the Bomblet Pit and other UXO disposal sites (including Five Points Landfill). These processing areas were designed for the detonation of bomblets and other UXO through the use of explosives (i.e., Compound C-4) as described in Section 3.2.3.2 of the VCA Work Plan and associated records of technical change. 
CAU No. 400: Bomblet

Pit and Five Points Landfill Section: 1.0

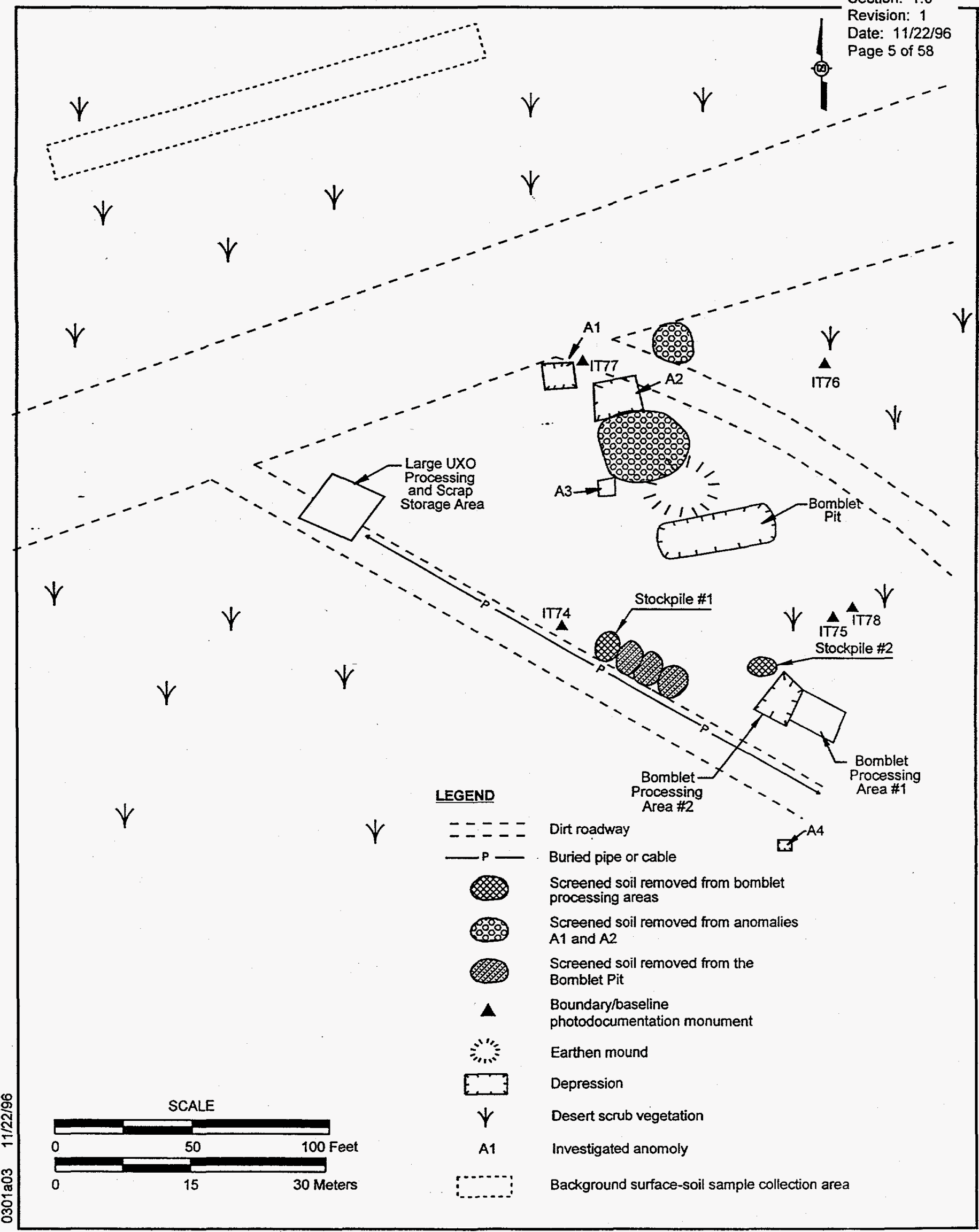

Figure 1-3

Site Location Map, Bomblet Pit,

Tonopah Test Range 
The areas of concern resulting from VCA activities at the Bomblet Pit site are the actual Bomblet Pit, Bomblet Processing Areas \#1 and \#2, the Large UXO Processing and Scrap Storage Area, and Stockpiles \#1 and \#2 (Figure 1-3). The areas of concern are defined as follows:

- Bomblet Pit: Ordnance disposal pit. Three detonations were conducted in the pit to sympathetically detonate ordnance buried in the walls or floor of the pit.

- Bomblet Processing Area \#1: Original processing area for bomblets. Used for approximately one-fourth of the total bomblet processing detonations. There were approximately 22,000 bomblets processed during the entire VCA project.

- Bomblet Processing Area \#2: Second processing area for bomblets. This area was excavated to approximately 0.76 meters $(\mathrm{m})(2.5 \mathrm{ft}[\mathrm{ft}])$ to provide better containment for

- detonation debris. This area is adjacent to Processing Area \#1 and was used for approximately three-fourths of the total bomblet processing detonations.

- Large UXO Processing and Scrap Storage Area: Large UXO and ordnance items were stored and processed/demilitarized here.

- Soil Stockpiles \#1 and \#2: Soil stockpiles generated from sifting soil from the bomblet processing areas for fuses. Sifting was performed after detonations in the areas.

In June of 1996, IT Corporation (IT) collected surface soil samples from the six areas of concern at the Bomblet Pit as part of SAFER Plan activities (DOE, 1996). Verification samples were collected from the three processing areas and the Bomblet Pit to determine if residual contamination from the explosive detonations and former UXO existed in concentrations requiring additional remediation. Characterization soil samples were collected from the two soil stockpiles to determine if concentrations of residual explosives residue above action levels existed within the piles.

\subsubsection{Five Points Landfill}

The Five Points Landfill is located approximately $2 \mathrm{~km}$ (1.2 mi) north of Five Points Intersection along Perimeter Road (Figure 1-2). The site consists of a fenced depression approximately $115 \mathrm{~m} \times 25 \mathrm{~m} \times 3 \mathrm{~m}(375 \mathrm{ft} \times 80 \mathrm{ft} \times 10 \mathrm{ft}$ ) with a mostly flat bottom. Surface debris (consisting of approximately 200 spent rocket motors, five 105 -millimeter inert projectiles, five MK82 $500-1 b$ inert bombs, four half-round corrugated metal and steel structures, four rocket motor ignitors, six bomblets, miscellaneous rocket motor parts [i.e., fins], concrete, wood, and wires) was found mostly along the north and south slopes of the depression and was removed during 
VCA activities (Figure 1-4). Refer to Section 3.2.4 of the VCA Work Plan and associated records of technical change for UXO removal activities.

During initial corrective action field activities, four half-round corrugated metal and steel structures were removed from the Five Points Landfill. The structures are approximately $2 \mathrm{~m} \times 2 \mathrm{~m} \times 1 \mathrm{~m}(6 \mathrm{ft} \times 6 \mathrm{ft} \times 3 \mathrm{ft})$ in size and partially full of soil. Due to the bullet-sized holes, these structures are believed to have been used as targets. The metal around several of the holes was found to be radiologically contaminated through field screening, and, although site personnel were unaware of the origin of the holes, it is believed that depleted uranium (DU) bullets were shot into the targets. The DU that remained within the soil in the targets was oxidized and bright yellow in color.

During target removal operations, some of the soil within the targets fell onto the ground within the main excavation area of the landfill. Approximately 0.1 cubic meters $\left(\mathrm{m}^{3}\right)$ (3.7 cubic feet $\left[\mathrm{ft}^{3}\right]$ ) of soil and DU pieces were removed from four areas within the pit, ranging in size from 2.5 centimeters $(\mathrm{cm}) \times 2.5 \mathrm{~cm}$ to $0.5 \mathrm{~m}$ to $1.4 \mathrm{~m}\left(1 \mathrm{inch}\right.$ [in.] $\times 1$ in. to $1 \frac{1}{2} \mathrm{ft} \times 41 / 2 \mathrm{ft}$ ), and placed in a 55-gallon drum. The four removal areas are within an 8-m x 6-m (26-ft x 20-ft) area along the south slope of the pit. The area of concern for Five Points Landfill is the area of the landfill that contained the debris and contaminated soil (Figure 1-4).

In June 1996, IT collected surface soil samples from the Five Points Landfill to verify that no residual contamination is present. The disposal of the radiologically contaminated items previously mentioned will be done in accordance with appropriate regulations and discussed under separate cover.

\subsection{Report Content}

To make this closure report a concise summary, the complete field documentation and laboratory data, including Field Activity Daily Logs, Sample Collection Logs, Analysis Request/Chain-ofCustody Forms, soil sample descriptions, laboratory certificates of analyses, analytical results, and surveillance results, are not contained in this report. These documents are retained in project files and will be supplied upon request. Descriptions of the site history, waste, and inventories which were discussed in detail in the SAFER Plan (DOE, 1996) will also not be repeated in this report. 


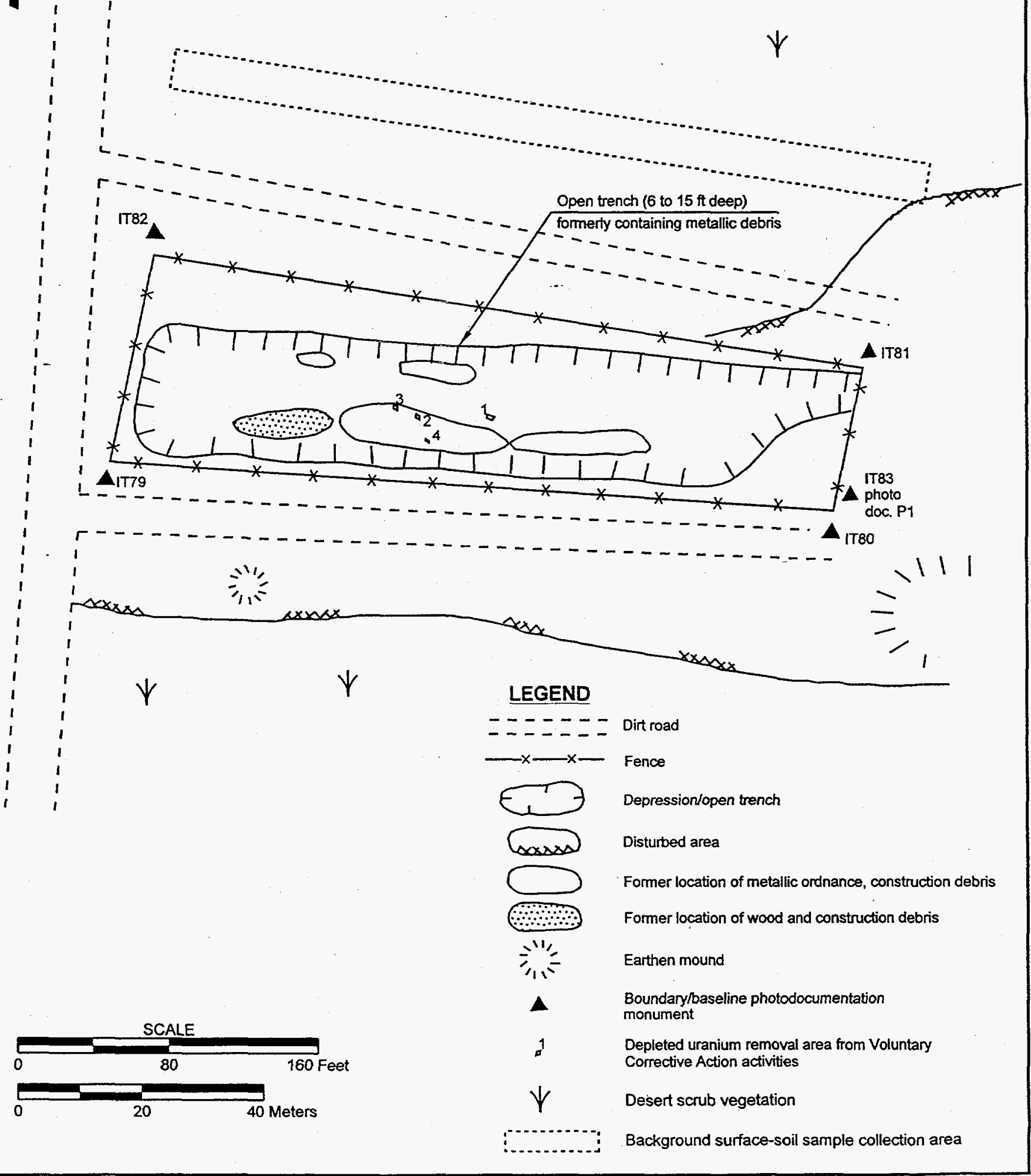




\subsection{Field and Sampling Activities}

The primary objective of the UXO removal activities at the Bomblet Pit and the Five Points Landfill was to prepare the sites for closure. The purpose of the verification sampling activities was to collect and analyze surface soil samples from the areas of concern at the sites to determine if additional soil excavation and remediation were required to obtain a clean closure for the sites. There were also two secondary objectives of the sampling activities. One was the collection of characterization samples from the soil stockpiles to determine the presence or absence of contaminants which would regulate the disposal of the soil. The second was the collection of background soil samples from both sites to determine the background metals concentrations for the Bomblet Pit and the background levels of radiological parameters at the Five Points Landfill.

Field investigation activities conducted for closure verification at the Bomblet Pit involved collecting surface soil samples from the Bomblet Pit, the two bomblet processing areas, the large UXO processing area, and the background sample location, as well as collecting a composite soil sample from each soil stockpile. At the Five Points Landfill, surface soil samples were collected from the bottom of the landfill and the designated background sample location.

Field activities were performed in accordance with an approved Site-Specific Health and Safety Plan. Samples were collected and documented by following approved procedures for sampling, field activity documentation, sample collection documentation, decontamination, Chain of Custody, shipping, and radiation screening protocols per the SAFER Plan (DOE, 1996) and the Field Instructions for Soil Sampling and Remediation Activities at the Bomblet Pit and Five Points Landfill, Tonopah Test Range (IT, 1996), hereafter referred to as Field Instructions. Quality control (QC) samples (e.g., field blanks, equipment rinsate blanks, and sample duplicates) were collected as required by the Quality Assurance Project Plan (QAPP) located in Appendix A of the SAFER Plan (DOE, 1996) and approved procedures (IT, 1996). All field and sample documentation records are maintained in project files. During the field activities for both the VCA and sampling activities, waste minimization practices included segregation of the waste from each site, segregation of suspected contaminated items from suspected uncontaminated items, and separation of personal protective equipment into bags. 


\subsection{Soil Sampling Logistics}

Prior to collecting verification samples from the three processing areas and the original pit at the Bomblet Pit site, a grid that divided the areas into quadrants was laid over each site. Each quadrant was then subdivided to assist in identifying the centers of the original quadrants. The grid was left in place until sample collection was complete. The sample locations were then marked with a 10 -in. nail, flagging, and a metal tag. The soil stockpiles were also divided into four quadrants designated simply as north, south, east, and west. Samples collected from the Bomblet Pit CAS were collected in the following order: TCLP metals, TCLP semivolatile organics, and total nitroaromatics and nitroamines. Background samples were collected only for TCLP metals analysis.

The footprint, or base, of the Five Points Landfill was divided into eight equal sections which were, in turn, divided into equal quadrants. Due to the size of the landfill and the potential for radiological contamination, a grid was not placed over the area. The section boundaries and center points were marked on the perimeter fence. As with the processing areas, the center points marked the sample locations. Each sample location was marked with a 10-in. nail, flagging, and metal tag after sampling.

Background sample locations for both sites were established between $100 \mathrm{ft}$ and $110 \mathrm{ft}$ upgradient, or north, of the Bomblet Pit and Five Points Landfill. The length of each background area traversed the width of each respective site. The length of the background area was divided into four sections, and sample locations were marked at the boundary of each section.

All the collected samples were placed on ice immediately after being placed in containers. As samples were collected, special care was taken to optimize the sample for its specific type of analysis. Sample containers were filled to eliminate or minimize headspace, and the rim was cleaned using the sampling tool or a gloved hand to ensure a good seal when closing the container. As samples were collected, notes about weather conditions, soil description, and sample quantities were recorded on Sample Collection Logs.

After each sampling event, the sampling team would place sample labels, indicating the sample number, date, and time, on each of the containers. Each of these containers was then placed into an individual "ziplock" bag and placed in a cooler, pending transport to the laboratory. A Chain 
of Custody was maintained and updated for each sample. Section 3.0 discusses the results of the sample analyses.

\subsection{Soil Sampling}

Sample locations were chosen to best represent the areas of concern. The methods described in the following text were chosen as a systematic way to obtain unbiased samples which would be representative of the entire area of concern. A total of 28 surface soil samples were collected from the Bomblet Pit using sample numbers TTR00031 through TTR00058. Fourteen surface soil samples (sample numbers TTR00060 through TTR00073) were collected from the Five Points Landfill. A description of sample collection activities at each area of concern is discussed in the following sections.

\subsubsection{Bomblet Pit}

Five surface soil samples (sample numbers TTR00038 through TTR00042) were collected from the Bomblet Pit from the locations specified in Section 2.1 (Figure 2-1). Because of activities performed during the VCA process, the sides of the pit sloughed onto the bottom of the pit. In order to obtain a soil sample representative of the native soil within the pit, the top 5 in. to 10 in. of soil were removed from each sample location prior to sampling. The soil was removed using a decontaminated shovel, and each sample was collected using a decontaminated, disposable, plastic trowel.

\subsubsection{Bomblet Processing Area \#1}

Four surface soil samples (sample numbers TTR00034 through TTR00037) were collected, one from the center of each quadrant, as discussed in Section 2.1 (Figure 2-2). The top 1 in. to 2 in. of weathered soil were removed from each sample location prior to sample collection to obtain a sample from the native soil. Each sample was collected using a decontaminated, disposable, plastic trowel.

\subsubsection{Bomblet Processing Area \#2}

Five surface soil samples (sample numbers TTR00043 through TTR00047) were collected from the center of each quadrant and from the center of the processing area (Figure 2-2) in a fashion similar to that used at the Bomblet Processing Area \#1. 
CAU No. 400: Bomblet Pit and Five Points Landfill

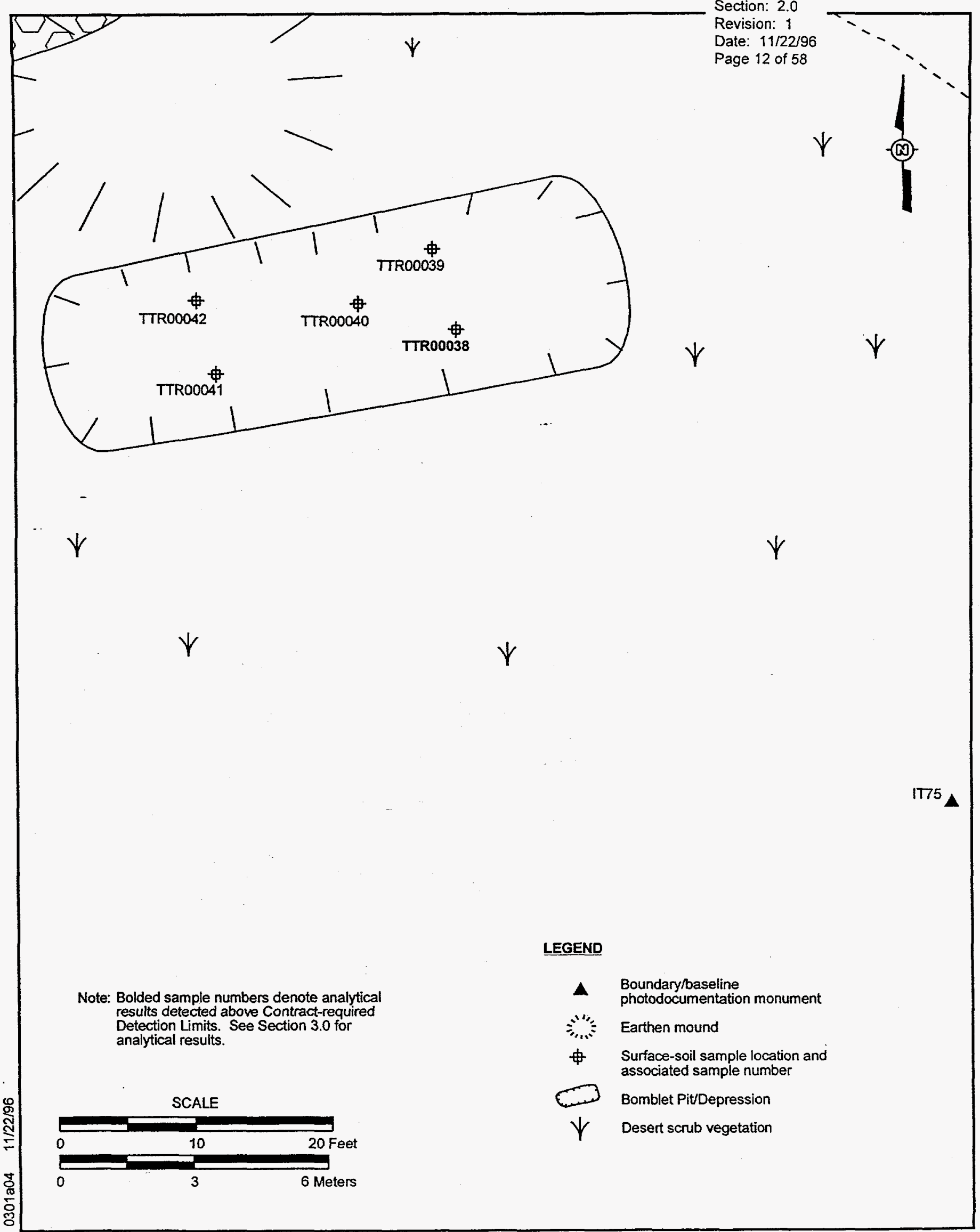

Figure 2-1

Sample Location Map, Bomblet Pit

Tonopah Test Range 


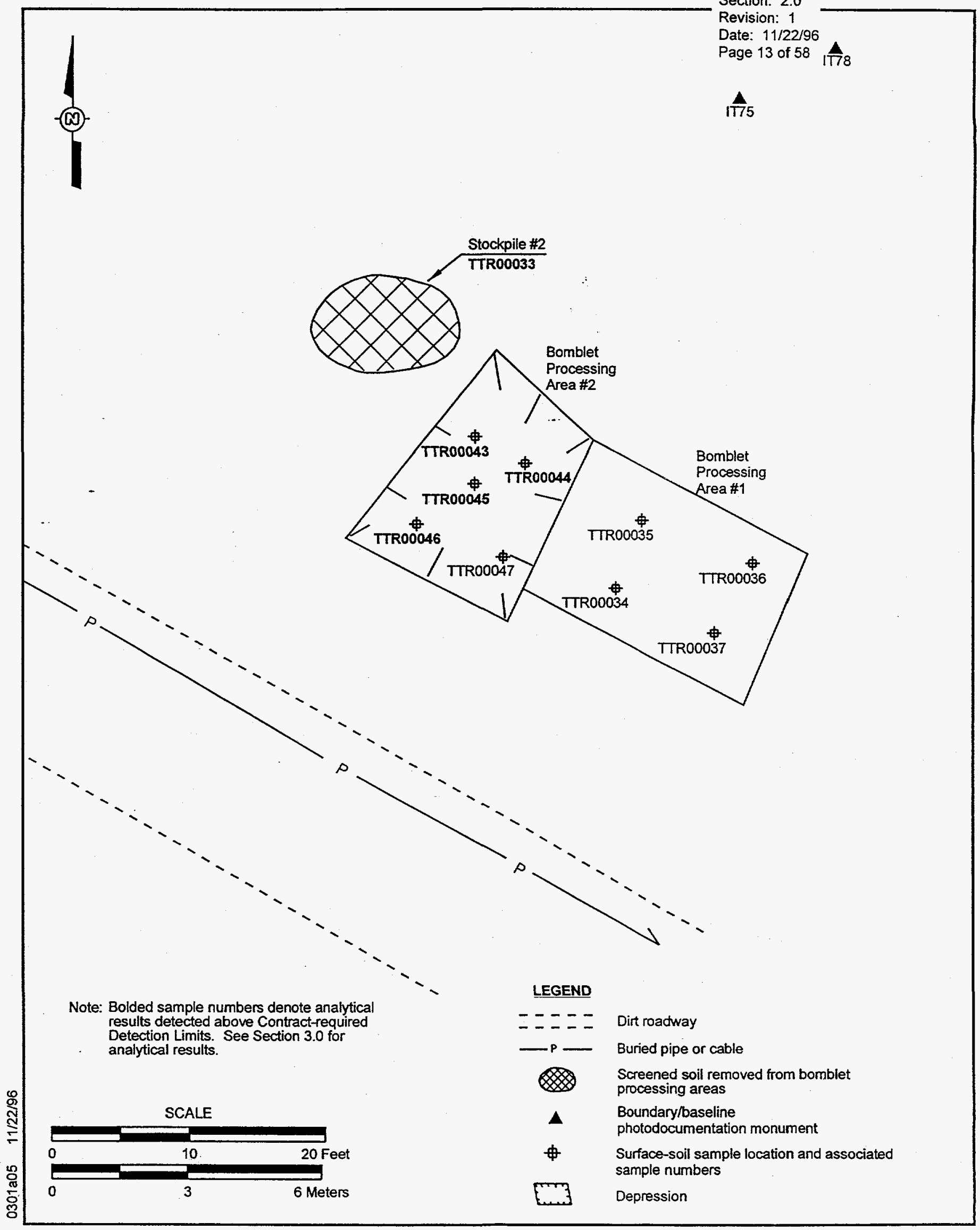

Figure 2-2

Sample Location Map, Bomblet Pit, Processing Areas \#1 and \#2, 


\subsubsection{Large UXO Processing and Scrap Storage Area}

Six surface soil samples (sample numbers TTR00048 through TTR00053) were collected from the center of each quadrant and from the center of the processing area in a fashion similar to that used at the Bomblet Processing Area \#1. The sixth sample, sample number TTR00052, is a field duplicate sample collected at the same location as TTR00051 (Figure 2-3).

\subsubsection{Stockpile \#1}

Two composite soil samples (sample numbers TTR00031 and TR00032) were collected from the stockpiled soil. The samples were composited from five grab soil samples collected from the north, south, east, and west quadrants and from the top of the pile. Sample TTR00032 is a duplicate composite sample from the stockpile. Figure 2-3 shows the location of Stockpile \#1.

\subsubsection{Stockpile \#2}

One composite soil sample (sample number TTR00033) was collected from the soil in Stockpile \#2. The samples were composited from five grab soil samples collected from the north, south, east, and west quadrants and from the top of the pile.

\subsubsection{Bomblet Pit Background Sample Area}

Five discrete surface soil samples (sample numbers TTR00054 through TTR00058) were collected from the established area as described in Section 2.1 (Figure 2-4).

\subsubsection{Five Points Landfill}

Nine surface soil samples (sample numbers TTR00060 through TTR00063 and TTR00069 through TTR00073) were collected from the center of each section of the landfill in a similar manner to the sampling process at the Bomblet Processing Area \#1. The ninth sample, sample number TTR00072, was a field duplicate sample collected at the same location as TTR00071 (Figure 2-5).

\subsubsection{Five Points Landfill Background Sample Area}

Five surface soil samples (sample numbers TTR00064 through TTR00068) were collected from the upgradient area north of the landfill, as described in Section 2.1 and illustrated in Figure 2-5. 
CAU No. 400: Bomblet

Pit and Five Points Landfill

Section: 2.0

Revision: 1

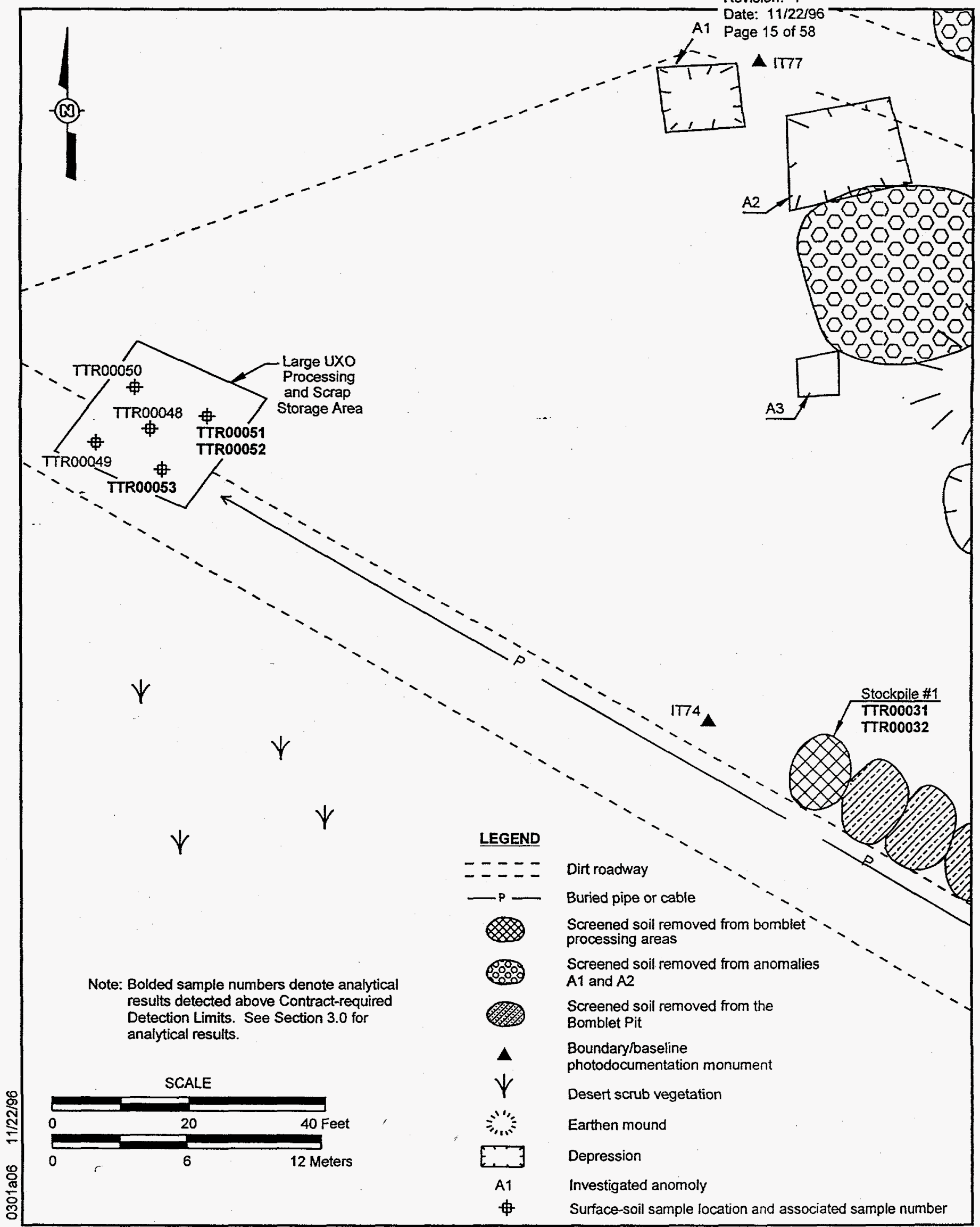

Figure 2-3

Sample Location Map, Large UXO Processing Area, Bomblet Pit, Tonopah Test Range 
CAU No. 400: Bomblet

Pit and Five Points Landfill

Section: 2.0

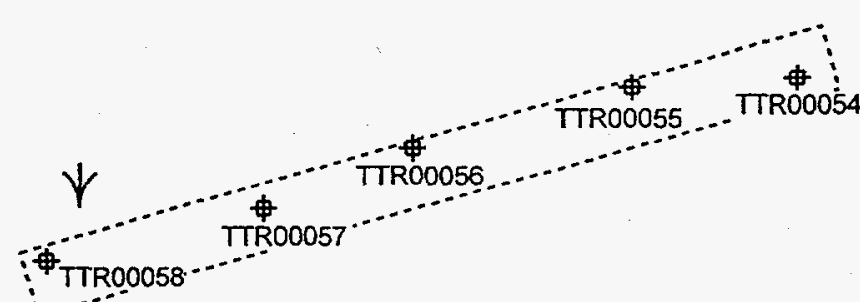

Revision: 1

Date: 11/22/96

Page 16 of 58

:....-

$\psi$

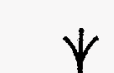

LEGEND

$$
\vee
$$

SCALE

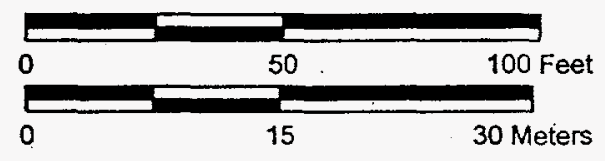

$$
\overline{- \pm-E}
$$

Dirt roadway

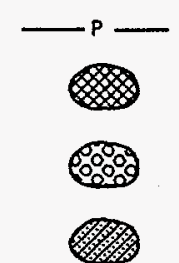

Buried pipe or cable

Screened soil removed from bomblet processing areas

Screened soil removed from anomalies A1 and A2

Screened soil removed from the Bomblet Pit

A Boundaryrbaseline photodocumentation monument

雚"

Earthen mound

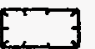

Depression

$\psi \quad$ Desert scrub vegetation

A1 Investigated anomoly

?.........

中
Background surface-soil sample collection area

Surface-soil sample location and associated sample numbers

Figure 2-4

Sample Location Map, Background Surface-Soil Collection Area, 


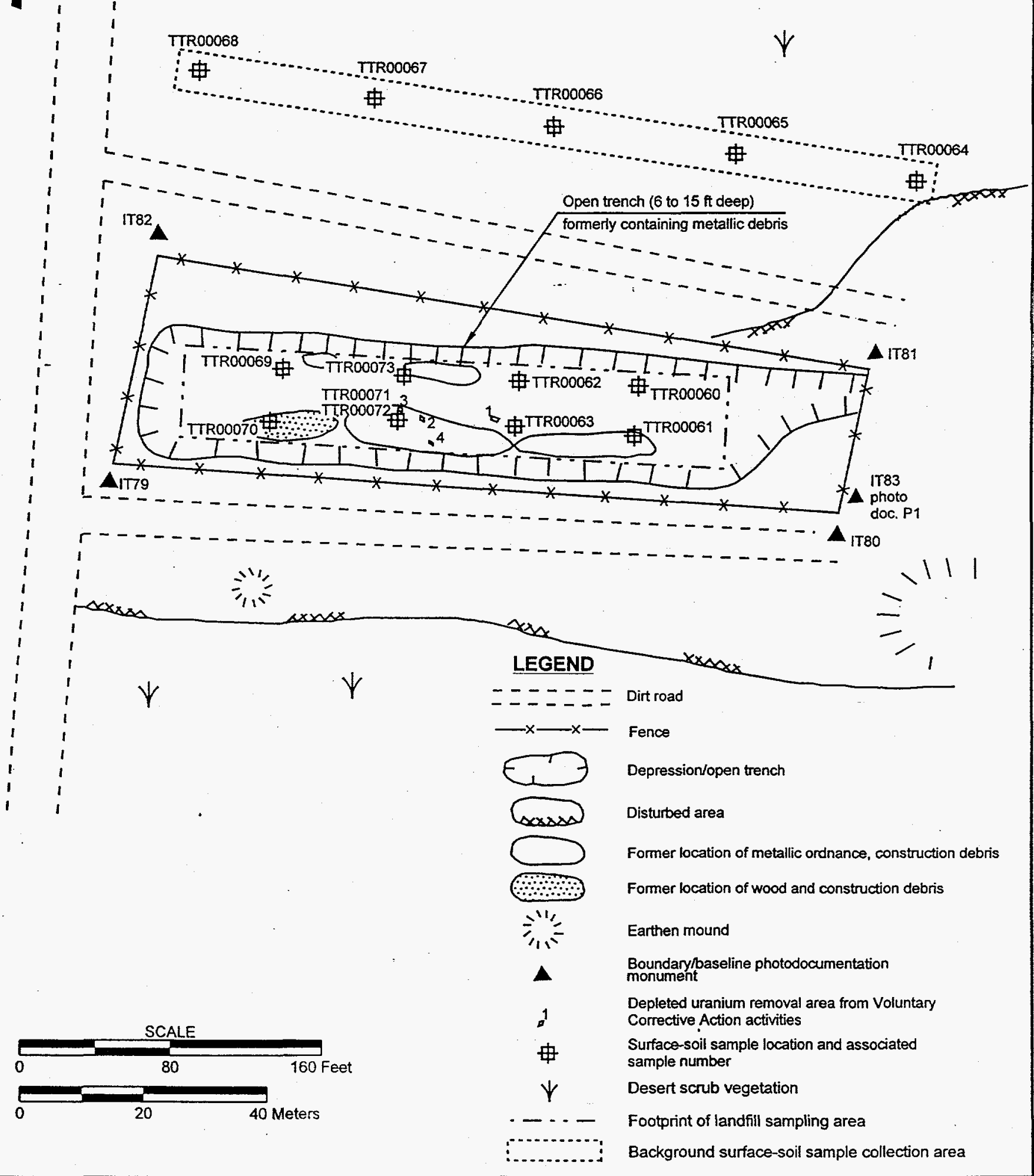

Figure 2-5

Sample Location Map, Five Points Landfill and Background Collection Area, Tonopah Test Range 



\subsection{Sampling Analytical Results}

The results of the off-site laboratory analysis of samples obtained from the Bomblet Pit and Five Points Landfill sites have been compiled and analyzed to determine the presence and, if applicable, the extent of contamination in the soil within the areas of concern at the sites. The analytical results are summarized in the following sections. The complete laboratory data packages are maintained in project files and are available upon request. Section 4.0 of this report presents a discussion and summary of quality control samples.

During the sampling activities, a total of 42 soil samples ( 28 from the Bomblet Pit and associated areas and 14 from Five Points Landfill and associated background area) were collected for anälysis. See Sections 2.2.1 through 2.2.9 for sample numbers and sample locations. Gaps in the numeric sample sequence represent rinsate and field blank (quality control) samples that are not included in this section but are discussed in Section 4.2 .

The sample analytical parameters, laboratory analytical methods, and closure standards, if applicable, are presented in Table 3-1. The sample analytical parameters were selected through the application of site process knowledge. Data Quality Objectives (DQOs) (EPA, 1994) were established for both sites based on process knowledge and can be found in Appendix $A$ of the SAFER Plan (DOE, 1996). Sampling activities were conducted either to confirm or to disprove the assumptions made in establishing the DQOs. The results of the DQO process are presented in the following sections. Samples collected from the Bomblet Pit were analyzed by Quanterra Environmental Services in Middlebrook, Tennessee. Samples collected from the Five Points Landfill were analyzed by Quanterra Environmental Services in St. Louis, Missouri. The parameters selected for analysis were based on the anticipated constituent of concerns associated with the debris contained within the sites and the activities known to have been conducted at the sites during VCA activities.

\subsection{Bomblet Pit Results}

A total of 28 surface soil samples were collected from the six areas of concern and the background sample location associated with the Bomblet Pit site. None of these samples showed any visual indications of contamination, and all of the analytical results were below closure 
Table 3-1

Suspected Constituents of Concern and Closure Standards

\begin{tabular}{|c|c|c|c|c|c|}
\hline Site & Group & Individual Constituents & Method $^{a}$ & $\begin{array}{l}\text { Closure } \\
\text { Standard } \\
(\mathrm{mg} / \mathrm{L})\end{array}$ & $\begin{array}{l}\text { Source of } \\
\text { Standard }\end{array}$ \\
\hline Bomblet Pit & TCLP ${ }^{c}$ Metals & $\begin{array}{l}\text { Arsenic } \\
\text { Barium } \\
\text { Cadmium } \\
\text { Chromium } \\
\text { Lead } \\
\text { Mercury } \\
\text { Selenium } \\
\text { Silver }\end{array}$ & $\begin{array}{l}1311 / 6010 \mathrm{~A} \\
1311 / 6010 \mathrm{~A} \\
1311 / 6010 \mathrm{~A} \\
1311 / 6010 \mathrm{~A} \\
1311 / 6010 \mathrm{~A} \\
1311 / 7470^{\mathrm{d}} \\
1311 / 6010 \mathrm{~A} \\
1311 / 6010 \mathrm{~A}\end{array}$ & $\begin{array}{c}5 \\
100 \\
1 \\
5 \\
5 \\
0.2 \\
1 \\
5\end{array}$ & $\begin{array}{l}\text { TCLP } \\
\text { TCLP } \\
\text { TCLP } \\
\text { TCLP } \\
\text { TCLP } \\
\text { TCLP } \\
\text { TCLP } \\
\text { TCLP }\end{array}$ \\
\hline $\begin{array}{c}\text { Bomblet Pit } \\
- \\
\end{array}$ & $\begin{array}{c}\text { TCLP } \\
\text { Semivolatile } \\
\text { Organics }\end{array}$ & $\begin{array}{l}\text { Nitrobenzene } \\
\text { 2,4-Dinitrotoluene }\end{array}$ & $\begin{array}{l}1311 / 8270 \\
1311 / 8270\end{array}$ & $\begin{array}{c}2 \\
0.13\end{array}$ & $\begin{array}{l}\text { TCLP } \\
\text { TCLP }\end{array}$ \\
\hline Bomblet Pit & $\begin{array}{c}\text { Nitroaromatics \& } \\
\text { Nitroamines }\end{array}$ & $\begin{array}{l}\text { Octahydro-1,3,5,7-tetranitro-1,3,5,7-tetrazocine (HMX) } \\
\text { Hexahydro-1,3,5-trinitro-1,3,5-triazine (RDX) } \\
\text { 1,3,5-Trinitrobenzene } \\
\text { 1,3-Dinitrobenzene } \\
\text { Methyl-2,4,6-trinitrophenylnitramine } \\
\text { 2,4,6-Trinitrotoluene } \\
\text { 4-Amino-2,6-dinitrotoluene } \\
\text { 2-Amino-4,6-dinitrotoluene } \\
\text { 2,6-Dinitrotoluene } \\
\text { 3-Nitrotoluene } \\
\text { 4-Nitrotoluene }\end{array}$ & $\begin{array}{l}8330^{e} \\
8330 \\
8330 \\
8330 \\
8330 \\
8330 \\
8330 \\
8330 \\
8330 \\
8330 \\
8330\end{array}$ & $\begin{array}{l}4000 \\
63.6 \\
4 \\
8.000 \\
800 \\
233.3 \\
1.029^{\mathrm{m}} \\
1.029^{\mathrm{m}} \\
80 \\
800 \\
800\end{array}$ & $\begin{array}{l}\text { Subpart S' } \\
\text { Subpart S } \\
\text { Subpart S } \\
\text { Subpart S } \\
\text { Subpart S } \\
\text { Subpart S } \\
\text { Subpart S } \\
\text { Subpart S } \\
\text { Subpart S } \\
\text { Subpart S } \\
\text { Subpart S }\end{array}$ \\
\hline $\begin{array}{c}\text { Five Points } \\
\text { Landfill }\end{array}$ & $\begin{array}{c}\text { Gamma } \\
\text { Spectroscopy }\end{array}$ & Uranium-238 & $\begin{array}{c}\text { HASL } 300 \\
4.5 \cdot 2.3^{f} \\
\end{array}$ & $500 \mathrm{pCi} / \mathrm{g}^{9}$ & RESRAD \\
\hline $\begin{array}{c}\text { Five Points } \\
\text { Landfill }\end{array}$ & Isotopic Uranium & Uranium-234-235 & $\begin{array}{c}\text { NAS-NS- } \\
3050^{i}\end{array}$ & $N A^{j}$ & NA \\
\hline $\begin{array}{c}\text { Five Points } \\
\text { Landfill }\end{array}$ & Isotopic Uranium & Uranium-238 & $\begin{array}{c}\text { NAS-NS- } \\
3050 \\
\end{array}$ & $500 \mathrm{pCi} / \mathrm{g}$ & RESRAD \\
\hline $\begin{array}{c}\text { Five Points } \\
\text { Landfill }\end{array}$ & $\begin{array}{l}\text { Isotopic } \\
\text { Plutonium }\end{array}$ & Plutonium-239 & $\begin{array}{c}\text { NAS-NS- } \\
3058^{k}\end{array}$ & NA & NA \\
\hline
\end{tabular}

${ }^{a}$ From SW-846 (EPA, 1992)

BMilligram(s) per liter

CToxicity Characteristic Leaching Procedure from Title 40 CFR $\$ 261.24$, Table 1 (CFR, 1993)

dMethod for Mercury

Proposed for addition to SW-846 (EPA, 1992)

'Environmental Measurements Laboratory Procedure Manual, HASL-300, U.S. Department of Energy (1992)

${ }^{\text {PPicoCurie(s) per gram }}$

heSRAD calculation (see Appendix A)

National Academy of Sciences, Nuclear Science Series, September 1963

$\mathrm{j}_{\text {Not Applicable }}$

National Academy of Sciences, Nuclear Science Series, September 1962

'All Resource Conservation and Recovery Act (RCRA) Subpart S values were calculated using EPA 1996. Subpart $S$ is a proposed section of 40 CFR $\$ 264$. (IT Telecon with Barbara Deshier, January 3, 1996)

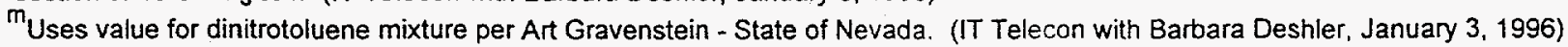


standards for the detected parameters. In most cases, the results were below CRDLs. The DQOs for the Bomblet Pit assumed that:

- The complete detonation of the UXO would result in the generation of a gaseous product of non-RCRA regulated constituents which would dissipate during detonation.

- The incomplete detonation of the UXO may result in the generation of certain nitroaromatics or nitramines which would remain in the soil.

- Metal constituents from the fuzes used for the processing of the UXO may remain in the soil after detonation.

Based on the analytical results, it is apparent that the DQOs were correct (see Sections 3.1.1 through 3.1.3).

\subsubsection{Inorganic Results}

The analytical results for the TCLP metals analysis are presented in Table 3-2. Cadmium was detected above the CRDL in Stockpiles \#1 and \#2 (Samples TTR00032 and TTR00033), the Bomblet Pit (Sample TTR00038), and the Bomblet Processing Area \#2 (Samples TTR00043 through TTR00046). Lead was detected above the CRDL within the Large UXO Processing and Storage Area (Sample TTR00052). None of these results, however, is above closure standards.

\subsubsection{Semivolatile Organics Results}

Analytical results for TCLP semivolatile organics analysis for all samples collected from the six areas of concern at the Bomblet Pit site were below CRDLs (Table 3-3).

\subsubsection{Nitroaromatics and Nitramines Results}

The analytical results for the total nitroaromatics and nitramines analysis are presented in Table 3-4. A constituent of the explosives used during VCA activities, RDX, was detected above the CRDL in Stockpile \#2 (TTR00033), the Bomblet Processing Area \#2 (TTR00043 through TTR00046), and the Large UXO Processing and Storage Area (TTR00051 through TTR00053). None of these results is above closure standards. 
Table 3-2

Summary of TCLP Metals Analytical Results for Soil Samples Collected from the Bomblet Pit

\begin{tabular}{|c|c|c|c|c|c|c|c|c|}
\hline \multirow{2}{*}{$\begin{array}{l}\text { Sample } \\
\text { Number }\end{array}$} & \multicolumn{8}{|c|}{ Constituents of Concern in milligrams per liter ( $\mathrm{mg} / \mathrm{L})$} \\
\hline & Arsenic & Barium & Cadmium & Chromium & Lead & Mercury & Selenium & Silver \\
\hline Detection Limit & 0.500 & 10.0 & 0.100 & 0.500 & 0.500 & 0.002 & 0.250 & 0.500 \\
\hline \multicolumn{9}{|l|}{ Stockpile \#1: } \\
\hline TTR00031 & ND & $\mathrm{ND}$ & ND & $\mathrm{ND}$ & $\mathrm{ND}$ & ND & ND & ND \\
\hline TTR00032 & ND & ND & 0.115 & ND & ND & ND & ND & ND \\
\hline \multicolumn{9}{|l|}{ Stockpile \#2: } \\
\hline TTR00033 & ND & ND & 0.192 & ND & ND. & ND & ND & ND \\
\hline \multicolumn{9}{|c|}{ Bomblet Processing Area \#1: } \\
\hline TTR00034 & $\mathrm{ND}$ & ND & $\mathrm{ND}$ & ND & ND & ND & ND & ND \\
\hline TIR00035 & ND & ND & ND & ND & ND & ND & ND & ND \\
\hline TTR00036 & ND & ND & ND & ND & ND & ND & ND & ND \\
\hline TTR00037 & ND & ND & ND & ND & ND & ND & ND & ND \\
\hline \multicolumn{9}{|l|}{ Bomblet Pit: } \\
\hline TTR00038 & ND & ND & 0.112 & ND & ND & ND & ND & ND \\
\hline TRR00039 & ND & ND & $\mathrm{ND}$ & ND & ND & ND & ND & ND \\
\hline TTR00040 & ND & ND & ND & ND & ND & ND & ND & ND \\
\hline TTR00041 & ND & ND & ND & ND & ND & ND & ND & ND \\
\hline TTR00042 & ND & ND & ND & ND & ND & ND & ND & ND \\
\hline \multicolumn{9}{|c|}{ Bomblet Processing Area \#2: } \\
\hline$\pi R 00043$ & ND & ND & 0.385 & ND & ND & ND & ND & ND \\
\hline TTR00044 & ND & ND & 0.174 & ND & ND & ND & ND & ND \\
\hline TTR00045 & ND & ND & 0.377 & ND & ND & ND & ND & ND \\
\hline TTR00046 & ND & ND & 0.512 & ND & ND & ND & ND & ND \\
\hline TTR00047 & ND & ND & ND & ND & ND & ND & ND & ND \\
\hline \multicolumn{9}{|c|}{ Large UXO Processing and Scrap Storage Area: } \\
\hline TTR00048 & ND & ND & ND & ND & ND & ND & ND & ND \\
\hline TTR00049 & ND & ND & ND & ND & ND & ND & ND & ND \\
\hline TIR00050 & ND & ND & ND & ND & ND & ND & ND & ND \\
\hline TTR00051 & ND & ND & ND & ND & ND & ND & ND & ND \\
\hline TTR00052 & ND & ND & ND & ND & 0.642 & ND & ND & ND \\
\hline TTR00053 & ND & ND & ND & ND & ND & ND & ND & ND \\
\hline \multicolumn{9}{|c|}{ Background Sampling Area: } \\
\hline TTR00054 & ND & ND & $\mathrm{ND}$ & ND & ND & ND & ND & ND \\
\hline TTR00055 & ND & ND & ND & ND & ND & ND & ND & ND \\
\hline TTR00056 & ND & ND & ND & ND & ND & ND & ND & ND \\
\hline TIR00057 & ND & ND & $\mathrm{ND}$ & ND & ND & $\mathrm{ND}$ & ND & ND \\
\hline TTR00058 & ND & ND & $\mathrm{ND}$ & $\mathrm{ND}$ & ND & $\mathrm{ND}$ & ND & $\mathrm{ND}$ \\
\hline
\end{tabular}


Table 3-3

Summary of TCLP Semivolatile Organics Analytical Results for Soil Samples Collected from the Bomblet Pit

(Page 1 of 2)

\begin{tabular}{|c|c|c|c|c|c|c|c|c|c|c|c|c|}
\hline \multirow{2}{*}{$\begin{array}{l}\text { Sample } \\
\text { Number }\end{array}$} & \multicolumn{12}{|c|}{ Constituents of Concern in milligrams per liter $(\mathrm{mg} / \mathrm{L})$} \\
\hline & $\begin{array}{c}\text { 1,4-Dichloro- } \\
\text { benzene }\end{array}$ & $\begin{array}{c}2,4,5 \text {-Trichloro- } \\
\text { phenol }\end{array}$ & $\begin{array}{c}2,4,6-T r i c h l o r o- \\
\text { phenol }\end{array}$ & $\begin{array}{c}2,4 \text {-Dinitro- } \\
\text { toluene }\end{array}$ & $\begin{array}{c}\text { Hexachloro- } \\
\text { benzene }\end{array}$ & $\begin{array}{c}\text { Hexachloro- } \\
\text { butadlene }\end{array}$ & $\begin{array}{c}\text { Hexachloro- } \\
\text { ethane }\end{array}$ & $\begin{array}{c}\text { m-Cresol \& } \\
\mathrm{p} \text {-Cresol }\end{array}$ & Nitrobenzene & 0. Cresol & $\begin{array}{c}\begin{array}{c}\text { Pentachloro- } \\
\text { phenol }\end{array} \\
\end{array}$ & Pyridine \\
\hline Detection Limit & 0.050 & 0.050 & 0.050 & 0.050 & 0.050 & 0.050 & 0.050 & 0.10 & 0.050 & 0.050 & 0.25 & 0.10 \\
\hline \multicolumn{13}{|l|}{ Stockpile \#1: } \\
\hline TIR00031 & ND & ND & ND & ND & ND & ND & ND & ND & ND & ND & ND & ND \\
\hline TTR00032 & ND & ND & ND & ND & ND & ND & ND & ND & ND & ND & ND & ND \\
\hline \multicolumn{13}{|l|}{ Stockpile \#2: } \\
\hline TTR00033 & ND & ND & ND & ND & ND & ND & ND & ND & ND & ND & ND & ND \\
\hline \multicolumn{13}{|c|}{ Bomblet Processing Area \#1: } \\
\hline TTR00034 & ND & ND & ND & ND & ND & ND & ND & ND & ND & ND & ND & ND \\
\hline TTR00035 & ND & ND & ND & ND & ND & ND & ND & ND & ND & ND & ND & ND \\
\hline TIR00036 & ND & ND & ND & ND & ND & ND & ND & ND & ND & ND & ND & $\mathrm{ND}$ \\
\hline TTR00037 & ND & ND & ND & ND & ND & ND & ND & ND & ND & ND & ND & ND \\
\hline \multicolumn{13}{|l|}{ Bomblet Pit: } \\
\hline TTR00038 & ND & ND & ND & ND & ND & ND & ND & ND & ND & $\mathrm{ND}$ & ND & ND \\
\hline TTR00039 & ND & ND & ND & ND & ND & ND & ND & ND & ND & ND & ND & ND \\
\hline TTR00040 & ND & ND & ND & ND & ND & ND & ND & ND & ND & ND & ND & ND \\
\hline TTR00041 & ND & ND & ND & ND & ND & ND & ND & ND & ND & ND & ND & ND \\
\hline TTR00042 & \begin{tabular}{|c|}
$N D$ \\
\end{tabular} & ND & ND & ND & ND & ND & ND & ND & ND & ND & ND & ND \\
\hline \multicolumn{13}{|c|}{ Bomblet Processing Area \#2: } \\
\hline$\pi R 00043$ & ND & ND & ND & ND & ND & ND & ND & ND & ND & ND & ND & ND \\
\hline TTR00044 & ND & ND & ND & ND & ND & ND & ND & ND & ND & ND & ND & ND \\
\hline TTR00045 & ND & ND & ND & ND & ND & ND & ND & ND & ND & ND & ND & ND \\
\hline TTR00046 & ND & ND & ND & ND & ND & ND & ND & ND & ND & ND & ND & ND \\
\hline TTR00047 & ND & \begin{tabular}{|c|}
$N D$ \\
\end{tabular} & ND & ND & ND & ND & ND & ND & ND & ND & ND & ND \\
\hline \multicolumn{13}{|c|}{ Large UXO Processing and Scrap Storage Area: } \\
\hline TTR00048 & \begin{tabular}{|c|}
$\mathrm{ND}$ \\
\end{tabular} & ND & ND & $N D$ & ND & ND & ND & ND & ND & ND & ND & ND \\
\hline TTR00049 & ND & ND & ND & ND & ND & ND & ND & ND & ND & ND & ND & ND \\
\hline TTR00050 & ND & ND & ND & ND & ND & ND & ND & ND & ND & ND & ND & ND \\
\hline TTR00051 & ND & ND & ND & ND & ND & ND & ND & ND & ND & ND & ND & ND \\
\hline
\end{tabular}


Table 3-3

Summary of TCLP Semivolatile Organics Analytical Results for Soil Samples Collected from the Bomblet Pit

(Page 2 of 2)

\begin{tabular}{|c|c|c|c|c|c|c|c|c|c|c|c|c|}
\hline \multirow{2}{*}{$\begin{array}{l}\text { Sample } \\
\text { Number }\end{array}$} & \multicolumn{12}{|c|}{ Constituents of Concern in milligrams per liter $(\mathrm{mg} / \mathrm{L})$} \\
\hline & $\begin{array}{c}\text { 1,4-Dichloro- } \\
\text { benzene }\end{array}$ & $\begin{array}{c}2,4,5-\text { Trichloro- } \\
\text { phenol }\end{array}$ & $\begin{array}{l}2,4,6 \text {-Trichloro- } \\
\text { phenol }\end{array}$ & $\begin{array}{c}\text { 2,4-Dinitro- } \\
\text { toluene }\end{array}$ & $\begin{array}{c}\text { Hexachloro- } \\
\text { benzene }\end{array}$ & $\begin{array}{l}\text { Hexachloro- } \\
\text { butadiene }\end{array}$ & $\begin{array}{c}\text { Hexachloro- } \\
\text { ethane }\end{array}$ & $\begin{array}{c}\text { m-Cresol \& } \\
\text { p-Cresol }\end{array}$ & Nitrobenzene & o-Cresol & $\begin{array}{c}\text { Pentachloro- } \\
\text { phenol }\end{array}$ & Pyridine \\
\hline Detection Limit & 0.050 & 0.050 & 0.050 & 0.050 & 0.050 & 0.050 & 0.050 & 0.10 & 0.050 & 0.050 & 0.25 & 0.10 \\
\hline \multicolumn{13}{|c|}{ Large UXO Processing and Scrap Storage Area (continued): } \\
\hline TTR00052 & ND & ND & $\mathrm{ND}$ & ND & ND & ND & ND & ND & ND & ND & ND & ND \\
\hline TRR00053 & ND & ND & ND & ND & ND & ND & ND & ND & ND & ND & ND & ND \\
\hline \multicolumn{13}{|c|}{ Background Sample Area: } \\
\hline$\pi R 00054$ & ND & $N D$ & ND & ND & ND & ND & ND & ND & ND & ND & ND & ND \\
\hline TTR00055 & ND & ND & ND & ND & ND & ND & ND & ND & ND & ND & ND & ND \\
\hline TTR00056 & ND & ND & ND & ND & ND & ND & ND & ND & ND & ND & ND & ND \\
\hline TTR00057 & ND & ND & ND & ND & ND & ND & ND & ND & ND & ND & ND & ND \\
\hline TTR00058 & ND & ND & ND & ND & ND & ND & ND & ND & ND & ND & ND & ND \\
\hline
\end{tabular}

ND $=$ Not Detected (at or above indicated detection limit) 
Table 3-4

Summary of Nitroaromatics and Nitroamines Analytical Results for

Soil Samples Collected from the Bomblet Pit

(Page 1 of 2)

\begin{tabular}{|c|c|c|c|c|c|c|c|c|c|c|c|}
\hline \multirow[b]{2}{*}{$\begin{array}{l}\text { Sample } \\
\text { Number }\end{array}$} & \multicolumn{11}{|c|}{ Constituents of Concern in milligrams per kilogram ( $\mathrm{mg} / \mathrm{kg})$} \\
\hline & $\begin{array}{c}1,3,5- \\
\text { Trinitrobenzene }\end{array}$ & $\begin{array}{c}1,3- \\
\text { Dinitrobenzene }\end{array}$ & $\begin{array}{c}2,4,6- \\
\text { Trinitrotoluene }\end{array}$ & $\begin{array}{c}2,6- \\
\text { Dinitrotoluene }\end{array}$ & $\begin{array}{l}\text { 2-Amino-4,6- } \\
\text { dinitrotoluene }\end{array}$ & 3-Nitrotoluene & $\begin{array}{c}\text { 4-Amino-2,6- } \\
\text { dinitrotoluene }\end{array}$ & HMX & Nitrobenzene & RDX & Tetryl \\
\hline Detection Limit ${ }^{\mathrm{a}}$ & 0.25 & 0.25 & 0.25 & 0.25 & 0.25 & 0.25 & 0.25 & 0.50 & 0.25 & 0.050 & 0.65 \\
\hline \multicolumn{12}{|l|}{ Stockpile \#1: } \\
\hline TTR00031 & ND & ND & ND & ND & ND & ND & ND & ND & ND & ND & ND \\
\hline TTR00032 & ND & ND & ND & ND & ND & ND & ND & ND & ND & ND & ND \\
\hline \multicolumn{12}{|l|}{ Stockpile \#2: } \\
\hline TR00033 & ND & ND & ND & ND & ND & ND & ND & ND & ND & 0.97 & ND \\
\hline \multicolumn{12}{|c|}{ Bomblet Processing Area \#1: } \\
\hline TRR00034 & ND & ND & ND & ND & ND & ND & ND & ND & ND & ND & ND \\
\hline TTR00035 & ND & ND & ND & ND & ND & ND & ND & ND & ND & ND & ND \\
\hline TTR00036 & ND & ND & ND & ND & ND & ND & ND & ND & ND & ND & ND \\
\hline TTR00037 & ND & ND & ND & ND & ND & ND & ND & ND & ND & ND & ND \\
\hline \multicolumn{12}{|l|}{ Bomblet Pit: } \\
\hline TTR00038 & ND & ND & ND & ND & ND & ND & ND & ND & ND & ND & ND \\
\hline TTR00039 & ND & ND & ND & ND & ND & ND & ND & ND & ND & ND & ND \\
\hline TTR00040 & ND & ND & ND & ND & ND & ND & ND & ND & ND & ND & ND \\
\hline TTR00041 & ND & NO & ND & ND & ND & ND & ND & ND & ND & ND & ND \\
\hline$\pi \mathrm{TR} 00042$ & ND & ND & ND & ND & ND & ND & ND & ND & ND & ND & ND \\
\hline \multicolumn{12}{|c|}{ Bomblet Processing Area \#2: } \\
\hline$\pi R 00043$ & ND & ND & ND & ND & ND & ND & ND & ND & ND & 1.1 & ND \\
\hline TTR00044 & ND & ND & ND & ND & ND & ND & ND & ND & ND & 2.3 & ND \\
\hline TTR00045 & ND & ND & ND & ND & ND & ND & ND & ND & ND & 0.75 & ND \\
\hline TTR00046 & ND & ND & ND & ND & ND & ND & ND & ND & ND & 1.3 & ND. \\
\hline TTR00047 & ND & ND & ND & ND & ND & ND & ND & ND & ND & ND & ND \\
\hline \multicolumn{12}{|c|}{ Large UXO Processing and Scrap Storage Area: } \\
\hline TTR00048 & ND & ND & ND & ND & ND & ND & ND & ND & ND & ND & ND \\
\hline TTR00049 & ND & ND & ND & ND & ND & ND & ND & ND & ND & ND & ND \\
\hline TRR00050 & ND & ND & ND & ND & ND & ND & ND & ND & ND & NND & ND \\
\hline TTR00051 & ND & ND & ND & ND & ND & ND & ND & ND & ND & 3.5 & ND \\
\hline TTR00052 & ND & ND & ND & ND & ND & ND & ND & ND & ND & 1.9 & ND \\
\hline TTR00053 & ND & ND & ND & ND & ND & ND & ND & ND & ND & 5.5 & ND \\
\hline
\end{tabular}


Table 3-4

Summary of Nitroaromatics and Nitroamines Analytical Results for Soil Samples Collected from the Bomblet Pit (Page 2 of 2)

\begin{tabular}{|c|c|c|c|c|c|c|c|c|c|c|c|}
\hline \multirow[b]{2}{*}{$\begin{array}{l}\text { Sample } \\
\text { Number }\end{array}$} & \multicolumn{11}{|c|}{ Constituents of Concern in milligrams per kilogram (mg/kg) } \\
\hline & $\begin{array}{c}1,3,5- \\
\text { Trinitrobenzene }\end{array}$ & $\begin{array}{c}1,3- \\
\text { Dinitrobenzene }\end{array}$ & $\begin{array}{c}2,4,6- \\
\text { Trinitrotoluene }\end{array}$ & $\begin{array}{c}2,6- \\
\text { Dinitrotoluene } \\
\end{array}$ & $\begin{array}{l}\text { 2-Amino-4,6- } \\
\text { dinitrotoluene }\end{array}$ & 3-Nitrotoluene & $\begin{array}{l}\text { 4-Amino-2,6- } \\
\text { dinitrotoluene }\end{array}$ & HMX & Nitrobenzene & RDX & Tetryl \\
\hline Detection Limit $^{\mathrm{a}}$ & 0.25 & 0.25 & 0.25 & 0.25 & 0.25 & 0.25 & 0.25 & 0.50 & 0.25 & 0.050 & 0.65 \\
\hline \multicolumn{12}{|c|}{ Background Sampling Area: } \\
\hline TTR00054 & ND & ND & ND & ND & ND & ND & ND & ND & ND & ND & ND \\
\hline TTR00055 & ND & ND & ND & ND & ND & ND & ND & ND & ND & ND & ND \\
\hline TTR00056 & ND & ND & ND & ND & ND & ND & ND & ND & ND & ND & ND \\
\hline TTR00057 & ND & ND & ND & ND & ND & ND & ND & ND & ND & ND & ND \\
\hline TTR00058 & ND & ND & ND & ND & ND & ND & ND & ND & ND & ND & ND \\
\hline
\end{tabular}

a Detection limits for sample TTR00053 are 2 times indicated limits.

ND $=$ Not Detected (at or above the indicated detection limit) 


\subsection{Five Points Landfill Results}

Fourteen surface soil samples were collected from the Five Points Landfill and the background sample location associated with the Five Points Landfill site. All sample locations were surveyed for radiological contamination prior to sample collection. Abnormal radiological survey readings were not obtained at any of the locations, and none of the locations showed any visual indications of contamination (e.g., pieces of DU). Radiological results for the samples are all near background levels or less. The DQOs for the Five Points Landfill assumed that radiological contamination could be present within the landfill due to the contaminated targets and soil removed from the area; however, analytical results have shown that contamination does not exist within the landfill.

\subsubsection{Gamma Spectroscopy Results}

Gamma spectroscopy analysis was performed to determine the concentration of DU decay products and fission products. Table 3-5 presents the gamma spectroscopy results. The concentration of the DU decay products is not different from the concentration found in soil taken from background locations. The gamma spectroscopy results demonstrate that the remedial activities at the Five Points Landfill reduced the DU decay product concentration to background.

\subsubsection{Isotopic Uranium Results}

Isotopic uranium results were deemed unusable due to unacceptably low recovery of the uranium tracers (matrix spikes) added to the soil samples. The chemical yield of the uranium tracer in the quality control samples were within the target range. Nevertheless, due to the low recovery of the uranium spike in the soil sample, it was considered prudent to evaluate an alternative method for determining the isotopic uranium concentration in the soil samples. Although uranium-238 is not a gamma emitter, several of its decay products are gamma emitters. Because the decay products are in secular equilibrium with uranium-238, their concentration in the soil is essentially the same as that of uranium-238. Using the gamma spectroscopy results, the maximum probable uranium-238 concentration was calculated to range from 7.2 to $18.7 \mathrm{pCi} / \mathrm{g}$. The most probable concentration for uranium-238 in the soil at the Five Points Landfill is in the range of 1.1 to $4.4 \mathrm{pCi} / \mathrm{g}$. The range of uranium-238 concentration in the soil is orders of magnitude less than the guideline concentration of $500 \mathrm{pCi} / \mathrm{g}$ (see Appendix A). The results demonstrate that the environmental remediation activities at the Five Points Landfill were successful in reducing the 
Table 3-5

Summary of Radiological Gamma Spectroscopy Results for

Soil Samples Collected from the Five Points Landfill

\begin{tabular}{|c|c|c|c|c|c|c|c|c|c|c|c|}
\hline \multirow{2}{*}{$\begin{array}{l}\text { Sample } \\
\text { Number }\end{array}$} & \multicolumn{11}{|c|}{ Constituents of Concern in picoCuries per gram (pCi/g) } \\
\hline & Bismuth-212 & Bismuth-214 & Cesium-137 & Lead-210 & Lead-212 & Lead-214 & Potassium-40 & Radium-226 & Radium-228 & Thallium-208 & Thorium-234 \\
\hline \multicolumn{12}{|c|}{ Five Points Landfill: } \\
\hline TTR00060 & $3.34 \pm 1.95$ & $N A$ & 0.46 & NA & $2.37 \pm 0.66$ & $1.24 \pm 0.56$ & $27.4 \pm 7.7$ & NA & NA & NA & NA \\
\hline TTR00061 & NA & $1.41 \pm 0.46$ & 0.32 & NA & $1.75 \pm 0.41$ & $1.50 \pm 0.55$ & $35.7 \pm 6.1$ & NA & NA & $0.58 \pm 0.26$ & NA \\
\hline TTR00062 & NA & $1.19 \pm 0.43$ & $0.44 \pm 0.26$ & $2.56 \pm 1.78$ & $1.60 \pm 0.26$ & $1.32 \pm 0.31$ & $31.8 \pm 5.6$ & NA & $1.77 \pm 0.53$ & $0.76 \pm 0.24$ & NA \\
\hline TTR00063 & NA & $1.06 \pm 0.34$ & $0.47 \pm 0.22$ & NA & $1.52 \pm 0.42$ & $0.90 \pm 0.39$ & $36.3 \pm 5.7$ & NA & $2.13 \pm 0.55$ & $0.64 \pm 0.29$ & NA \\
\hline TTR00069 & NA & $1.07 \pm 0.39$ & $0.75 \pm 0.23$ & $2.34 \pm 1.75$ & $1.96 \pm 0.30$ & $1.34 \pm 0.36$ & $33.2 \pm 5.3$ & $3.59 \pm 4.04$ & $2.29 \pm 0.63$ & $1.02 \pm 0.23$ & NA \\
\hline TTR00070 & NA & NA & $0.53 \pm 0.28$ & NA & $2.00 \pm 0.69$ & NA & $26.8 \pm 6.8$ & NA & NA & $0.69 \pm 0.40$ & NA \\
\hline TTR00071 & NA & NA & 0.32 & NA & $1.81 \pm 0.42$ & NA & $35.0 \pm 5.6$ & $N A$ & NA & NA & $3.96 \pm 1.85$ \\
\hline TTR00072 & $2.05 \pm 1.46$ & $N A$ & $0.29 \pm 0.19$ & NA & $1.65 \pm 0.27$ & $1.23 \pm 0.33$ & $30.7 \pm 5.5$ & $4.43 \pm 2.87$ & $1.94 \pm 0.64$ & $0.80 \pm 0.23$ & $3.36 \pm 1.39$ \\
\hline TTR00073 & NA & $1.89 \pm 0.46$ & $1.03 \pm 0.24$ & $2.91 \pm 1.98$ & $1.76 \pm 0.32$ & $1.62 \pm 0.38$ & $32.2 \pm 5.4$ & $3.05 \pm 2.88$ & $2.36 \pm 0.56$ & $0.69 \pm 0.23$ & NA \\
\hline \multicolumn{12}{|c|}{ Background Sample Area: } \\
\hline TTR00064 & NA & NA & $0.32 \pm 0.20$ & NA & $1.70 \pm 0.33$ & $1.03 \pm 0.30$ & $36.4 \pm 5.7$ & NA & $1.63 \pm 0.55$ & $0.83 \pm 0.23$ & $2.22 \pm 1.29$ \\
\hline TTR00065 & $3.40 \pm 1.79$ & NA & 0.41 & NA & $2.05 \pm 0.52$ & NA & $30.6 \pm 6.4$ & NA & NA & $0.49 \pm 0.44$ & NA \\
\hline TTR00066 & NA & NA & 0.26 & NA & $1.88 \pm 0.36$ & NA & $31.4 \pm 5.4$ & NA & NA & $0.80 \pm 0.25$ & NA \\
\hline TTR00067 & NA & NA & $0.27 \pm 0.16$ & $2.08 \pm 2.02$ & $1.55 \pm 0.25$ & $1.26 \pm 0.32$ & $32.7 \pm 6.0$ & $3.54 \pm 2.44$ & $2.19 \pm 0.65$ & $0.76 \pm 0.21$ & NA \\
\hline TTR00068 & NA & NA & $0.25 \pm 0.16$ & NA & $2.19 \pm 0.49$ & $1.17 \pm 0.38$ & $33.6 \pm 5.5$ & NA & $2.26 \pm 0.65$ & $0.73 \pm 0.20$ & NA \\
\hline
\end{tabular}


uranium-238 concentrations to orders of magnitude less than the guideline concentration and to concentrations not significantly greater than background. Appendix A presents an explanation of the calculations that were performed.

\subsubsection{Isotopic Plutonium Results}

Table 3-6 presents isotopic plutonium results. Plutonium-239/240 concentrations detected in one of the background samples (TTR00065) and in one of the Five Points Landfill samples (TTR00072) were anomalously higher than the other samples, but still well below concentrations in other background samples collected from the Nevada Test Site (NTS) and other TTR areas. Process knowledge of the background sample area did not indicate potential contamination prior to sample collection. These results should not affect the closure decision for the landfill.

Table 3-6

Summary of Radiological (Isotopic) Results for Soil Samples Collected from the Five Points Landfill

\begin{tabular}{|c|c|c|}
\hline \multirow{2}{*}{ Sample Number } & \multicolumn{2}{|c|}{ Constituents of Concern in picoCuries per gram ( $\mathrm{pCi} / \mathrm{g})$} \\
\hline & Plutonium-238 & Plutonium-239/240 \\
\hline \multicolumn{3}{|l|}{ Five Points Landfill: } \\
\hline TTR00060 & $0.11 \pm 0.11$ & $0.10 \pm 0.11$ \\
\hline TTR00061 & $-0.06 \pm 0.03$ & $<0.21 \pm 0.07$ \\
\hline TTR00062 & $-0.03 \pm 0.02$ & $<0.20 \pm 0.60$ \\
\hline TTR00063 & $0.02 \pm 0.07$ & $0.03 \pm 0.07$ \\
\hline TTR00069 & $0.02 \pm 0.06$ & $0.08 \pm 0.09$ \\
\hline TTR00070 & $0.02 \pm 0.08$ & $0.06 \pm 0.10$ \\
\hline TTR00071 & $-0.03 \pm 0.08$ & $0.16 \pm 0.14$ \\
\hline TTR00072 & $0.15 \pm 0.13$ & $2.45 \pm 0.66$ \\
\hline TTR00073 & $-0.01 \pm 0.05$ & $0.22 \pm 0.16$ \\
\hline \multicolumn{3}{|l|}{ Background Sample Area: } \\
\hline TTR00064 & $0.14 \pm 0.14$ & $0.06 \pm 0.08$ \\
\hline TTR00065 & $0.04 \pm 0.08$ & $2.05 \pm 0.58$ \\
\hline TTR00066 & $0.072 \pm 0.095$ & $0.006 \pm 0.075$ \\
\hline TTR00067 & $0.10 \pm 0.12$ & $-0.008 \pm 0.054$ \\
\hline TTR00068 & $-0.03 \pm 0.02$ & $-0.01 \pm 0.01$ \\
\hline
\end{tabular}





\subsection{Quality Assurance}

The results of quality assurance (QA) and QC activities for the Bomblet Pit and Five Points Landfill characterization sampling event are summarized in the following section, including a discussion about quantifying the QA/QC objectives and documentation of nonconformances. Detailed information on the QA program for this sampling event is contained in the QAPP in Appendix A of the SAFER Plan for the Bomblet Pit and Five Points Landfill (DOE, 1996).

\subsection{Quality Control Samples}

Quality control samples were collected and analyzed throughout the Bomblet Pit and Five Points Landfill sample collection process. A list of collected field QC samples is presented on Table 4-1. A total of two field blanks, one equipment rinsate blank, two matrix spike/matrix spike duplicates (MS/MSD), and three field duplicates were collected and submitted for laboratory analysis. The samples and duplicates were assigned individual sample numbers and sent to the laboratory blind. Additional samples were selected by the laboratory to be analyzed as laboratory duplicates. Trip blanks were not used since analyses for volatile organic compounds were not performed. The field blanks were taken by placing distilled water into appropriate sample bottles and preserving them according to the requirements specified in the Bomblet Pit and Five Points Landfill SAFER Plan (DOE, 1996). The equipment rinsate blank was obtained by collecting the final rinse solution (i.e., distilled water) which was poured over the decontaminated sampling equipment into the appropriate sample bottles and preserved as applicable. The results of the QC samples are discussed in the following sections.

\subsubsection{Field Quality Control Samples}

Review of the field blank analytical data for the characterization sampling indicated that crosscontamination from field methods did not occur during sample collection. The field blanks (TTR00059 and TTR00074) were analyzed for the parameters listed in Table 4-2, and none of the COCs was identified above the detection limits.

The equipment rinsate blank (TTR00030) was collected from the sampling equipment used during the characterization and was analyzed for the parameters listed on Table 4-2. In this blank, none of the COCs was identified above the detection limits. 
Table 4-1

Bomblet Pit and Five Points Landfill Quality Control Samples Collected for Laboratory Analysis

\begin{tabular}{|c|c|c|c|}
\hline $\begin{array}{l}\text { Sample } \\
\text { Location }\end{array}$ & $\begin{array}{l}\text { Sample } \\
\text { Number }\end{array}$ & Sample Type & Notes \\
\hline NA & TTR00030 & Rinsate blank & \\
\hline \multirow{5}{*}{$\begin{array}{l}\text { Bomblet } \\
\text { Pit }\end{array}$} & TTR00032 & Field duplicate & Duplicate of TTR00031 \\
\hline & TTR00033 & MS/MSD & $\begin{array}{l}\text { Characterization sample collected with } \\
\text { extra volume for MS/MSD analysis }\end{array}$ \\
\hline & TTR00047 & MS/MSD & $\begin{array}{l}\text { Characterization sample collected with } \\
\text { extra volume for MS/MSD analysis }\end{array}$ \\
\hline & TTR00052 & Field duplicate & Duplicate of TTR00051 \\
\hline & TTR00059 & Field blank & \\
\hline \multirow{2}{*}{$\begin{array}{l}\text { Five } \\
\text { Points } \\
\text { Landfill }\end{array}$} & TTR00072 & Field duplicate & Duplicate of TTR00071 \\
\hline & TTR00074 & Field blank & \\
\hline
\end{tabular}

NA $=$ Not applicable

Table 4-2

Analytical Methods Used for Analysis of Quality Control Samples

\begin{tabular}{|c|c|c|}
\hline Sample Location & Analytical Parameter & Analytical Method \\
\hline \multirow[t]{3}{*}{ Bomblet Pit } & TCLPa Semivolatile Organic Compounds & EPA $1311 / 8270^{b}$ \\
\hline & TCLP Metals & EPA $1311 / 6010 A 7470^{b}$ \\
\hline & Nitroaromatics and Nitroamines & EPA $8330^{\circ}$ \\
\hline \multirow[t]{3}{*}{ Five Points Landfill } & $\begin{array}{l}\text { Gamma Spectroscopy } \\
\text { (based on cesium-137) }\end{array}$ & $\begin{array}{l}\text { HASL300, } 4.5 .2 .3^{\mathrm{c}} \text { (soil) } \\
\text { EPA } 901.1^{\mathrm{d}} \text { (water) }\end{array}$ \\
\hline & Isotopic Uranium & NAS-NS-3050 \\
\hline & Isotopic Plutonium & NAS-NS-3058 ${ }^{f}$ \\
\hline
\end{tabular}

${ }^{a}$ Toxicity characteristic leaching procedure

b U.S. Environmental Protection Agency SW-846 (EPA, 1992)

Environmental Measurements Laboratory Procedure Manual, HASL-300 (DOE, 1992)

Standard Methods for the Examination of Water and Waste Water (APHA, 1992)

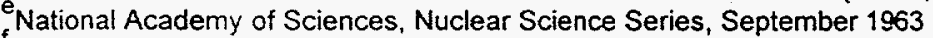

National Academy of Sciences, Nuclear Science Series, September 1962 
During the actual sampling event, field duplicates TTR00032, TTR00052, and TTR00072 were collected and analyzed for the parameters listed on Table 4-2. The field duplicate sampling results indicating the presence of COCs are listed on Tables 3-2 through 3-6 in Section 3.0 of this report along with all other sample results.

Review of the laboratory analytical data from the field and rinsate blanks indicates that the Bomblet Pit and Five Points Landfill soil samples were not contaminated during field activities or shipment and that cross contamination, due to incomplete decontamination, did not occur.

\subsubsection{Laboratory Quality Control Samples}

Analysis of method QC blanks and laboratory control samples was performed for each parameter analyzed by Quanterra. Two samples were also designated for matrix spike/matrix spike duplicate analyses. In addition, laboratory duplicate (sample split) analysis was performed on sample TTR00072 for radiological parameters only. In general, the laboratory duplicate results were considered to be in agreement with the original sample results. The complete QC sample results are maintained in the project files and available upon request.

\subsection{Quality Assurance Objectives Measurements}

The QA objectives ensure that the analytical data collected are meaningful, defensible, and can be used for the desired purposes. Evaluation of specific QA objectives is discussed in the following sections. Minimum requirements for each measurement are specified in the SAFER Plan (DOE, 1996).

\subsubsection{Precision}

Precision is a quantitative measure of the variability of a group of measurements from their average value. Additional information regarding the measurement of precision may be found in the Bomblet Pit and Five Points Landfill SAFER Plan (DOE, 1996). Precision is assessed by collecting and analyzing duplicate field samples and comparing the results with the original sample. Precision is also assessed by creating, analyzing, and comparing laboratory duplicates from one or more field samples. Precision is reported as relative percent difference (RPD), which is calculated as the difference between the measured concentrations of duplicate samples, divided by the average of the two concentrations, and multiplied by 100 . For this sampling project, the accepted precision goals for laboratory analyses are specified in the SAFER Plan 
(DOE, 1996) and are listed on Table 4-3, which also presents the results of measurement of precision for the Bomblet Pit and Five Points Landfill sampling data. The table lists, by analysis type, the total number of RPD precision measurements used, the acceptable (i.e., target) RPD range per the SAFER Plan (DOE, 1996), and the number and percent of precision RPD measurements within the acceptance range.

Table 4-3

Laboratory Precision Measurements for Bomblet Pit and Five Points Landfill Surface Soil Sampling Data

\begin{tabular}{|c|c|c|c|c|c|c|c|}
\hline \multirow{3}{*}{ - Parameter } & \multicolumn{6}{|c|}{ Field Duplicate and Laboratory Duplicate Totals } & \multirow{3}{*}{ Total } \\
\hline & \multicolumn{3}{|c|}{ Bomblet Pit } & \multicolumn{3}{|c|}{ Five Points Landfill } & \\
\hline & svocs $^{a}$ & TC Metals & $\begin{array}{l}\text { Nitroaromatics } \\
\quad \text { and } \\
\text { Nitroamines }\end{array}$ & $\begin{array}{l}\text { Gamma } \\
\text { Scan }\end{array}$ & $\begin{array}{l}\text { Isotopic } \\
\text { Uranium }\end{array}$ & $\begin{array}{l}\text { Isotopic } \\
\text { Plutonium }\end{array}$ & \\
\hline $\begin{array}{l}\text { Total Number of RPD } \\
\text { Precision Measurements }\end{array}$ & 19 & 32 & 28 & 11 & 7 & 4 & 101 \\
\hline $\begin{array}{l}\text { Actual Range of Precision } \\
\text { RPD Results }\end{array}$ & $0-19.7$ & $0.1-5.0$ & $0-66.7$ & $1.0-34.3$ & $21.1-174.8$ & $30.8-196.8$ & NA \\
\hline $\begin{array}{l}\text { Target Range for Precision } \\
\text { RPD }^{\text {d }}\end{array}$ & \pm 25 & \pm 20 & $\begin{array}{l} \pm 30 \text { (soil) } \\
\pm 20 \text { (water) }\end{array}$ & \pm 20 & \pm 25 & \pm 25 & NA \\
\hline $\begin{array}{l}\text { Number of Precision RPD } \\
\text { Measurements within Target } \\
\text { Range }\end{array}$ & 19 & 32 & $\begin{array}{l}17 \text { (soil) } \\
9 \text { (water) }\end{array}$ & 10 & 1 & 0 & 79 \\
\hline $\begin{array}{l}\text { Percent of Precision RPD } \\
\text { Measurements within Target } \\
\text { Range }\end{array}$ & 100 & 100 & 92.9 & 90.9 & 14.2 & 0 & 78.2 \\
\hline
\end{tabular}

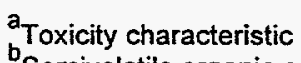

Semivolatile organic compounds

CRelative percent difference

${ }^{d}$ As per the Bomblet Pit and Five Points Landfill SAFER Plan (DOE, 1996)

The values shown on Table 4-3 indicate excellent precision between field samples and field and laboratory duplicates for chemical parameters. For radiological parameters, particularly isotopic plutonium and isotopic uranium, precision was fair to poor. This was most likely because the radiological analyte concentrations for these samples were, in general, very close to the minimum detectable activity levels (MDAs). Typically, the precision of data that are near the MDAs is relatively poor, and this was the case for the Five Points Landfill isotopic uranium and isotopic plutonium data. In addition, the laboratory was unable to demonstrate analytical 
precision for an isotopic plutonium sample and its duplicate TTR00071 and TTR00072; however, imprecision of data was not great enough to require the data to be qualified. Overall, approximately 78.2 percent of the precision measurements were within the specified parameterspecific target ranges for both the chemical and radiological data.

\subsubsection{Accuracy}

Analytical accuracy is defined as the nearness of a measurement to the true or accepted reference value. It is the composite of the random and systematic components of the measurement system, and it quantifies bias in a measurement system. The random component of accuracy is measured and documented through the analyses of spiked samplès. Sampling accuracy is assessed by evaluating the results of spiked samples and laboratory control samples. Accuracy measurements are calculated as percent recovery by dividing the measured sample concentration by the true concentration and multiplying the quotient by 100 .

The target accuracy ranges established for the Bomblet Pit and Five Points Landfill samples, and the actual accuracies that were achieved are shown on Table 4-4 for both matrix spike and laboratory control samples. Based on the results shown on this table, 99.1 percent of all QC sample recoveries were within the acceptable limits, indicating excellent analytical accuracy. Additional information about measurement of accuracy for these samples is found in the SAFER Plan QAPP (DOE, 1996). Parameter-specific accuracy (percent recovery) measurements may be found in the laboratory analytical report data package maintained in the project files.

It should be noted that, although 75 percent of the accuracy (percent recovery) measurements for laboratory control samples for isotopic uranium were within the target range (see Table 4-4), the isotopic uranium characterization data associated with these laboratory control samples were rejected due to low recovery of the uranium tracers used to spike the soil samples. Laboratory control samples are analyzed using a homogeneous matrix (such as a clean sand). As a result, the percent recovery values achieved tend to be higher than recovery values obtained from the characterization samples which have heterogeneous soil matrices as well as relatively high concentrations of natural metals that also contribute to matrix interference. 
Table 4-4

Laboratory Accuracy Measurements for Bomblet Pit and Five Points Landfill Surface Soil Sampling Data

\begin{tabular}{|c|c|c|c|c|c|c|c|}
\hline \multirow[b]{2}{*}{ Parameter } & \multicolumn{3}{|c|}{ Bomblet Pit } & \multicolumn{3}{|c|}{ Five Points Landfill } & \multirow[b]{2}{*}{ Tota } \\
\hline & $\begin{array}{l}\text { TCLPa } \\
\text { Metals }\end{array}$ & $\begin{array}{c}\text { TCLP } \\
\text { Semivolatile } \\
\text { Organic } \\
\text { Compounds }\end{array}$ & $\begin{array}{l}\text { Nitroaromatics/ } \\
\text { Nitroamines }\end{array}$ & $\begin{array}{l}\text { Gamma } \\
\text { Scan }\end{array}$ & $\begin{array}{l}\text { Isotopic } \\
\text { Uranium }^{b}\end{array}$ & $\begin{array}{l}\text { Isotopic } \\
\text { Plutonium }\end{array}$ & \\
\hline $\begin{array}{l}\text { Total Number of } \\
\% R^{c} \text { Measurements }\end{array}$ & 72 & 344 & 105 & 9 & 8 & 6 & 544 \\
\hline $\begin{array}{l}\text { Matrix Spike } \\
\text { Samples (range of } \\
\text { actual percent } \\
\text { recoveries }[\% R] \text { ) }\end{array}$ & $91.1-111.6$ & $36-133$ & $25-116$ & $N A^{d}$ & $1-3^{e}$ & NA & - \\
\hline $\begin{array}{l}\text { Laboratory Control } \\
\text { Samples (range of } \\
\text { actual \%R). }\end{array}$ & $87.1-115.6$ & $0^{f}-122$ & $67-103$ & $99-114$ & $108-142$ & $72-100$ & - \\
\hline $\begin{array}{l}\text { \%R Target Range } \\
\text { (Water) }\end{array}$ & $80-120$ & $1-180$ & $53-133$ & $80-120$ & $70-120$ & $75-125$ & - \\
\hline $\begin{array}{l}\% R \text { Target Range } \\
\text { (Soil) - }\end{array}$ & $80-120$ & $1-180$ & $22-157$ & $80-120$ & $70-120$ & $75-125$ & - \\
\hline $\begin{array}{l}\text { Number of \%R } \\
\text { Measurements } \\
\text { within the Target } \\
\text { Range }\end{array}$ & 72 & 342 & 105 & 9 & 6 & 5 & 539 \\
\hline $\begin{array}{l}\text { Percent of \%R } \\
\text { Measurements } \\
\text { within the Target } \\
\text { Range }\end{array}$ & 100 & 99.4 & 100 & 100 & 75 & 83.3 & 99.1 \\
\hline
\end{tabular}

${ }_{b}^{a}$ Toxicity characteristic leaching procedure

Associated characterization data for isotopic uranium were rejected as unusable due to low recovery of uranium tracers.

See Sections 3.2.2 and 4.2.2 for additional discussion.

Percent recovery

Not applicable

Range of tracer recoveries from validated samples. These validated data findings were used for all Isotopic uranium results.

Pyridine results for TTR00038 and TTR00046 were qualified as unusable due to $0 \%$ recovery of pyridine in the laboratory control sample.

$9_{\text {As per the Bomblet Pit and Five Points Landfill SAFER Plan (DOE, 1996) }}$ 
Field accuracy is assessed by confirming that the documents of record track the sample from its origin, through transfer of custody, to its disposal. The goal of field accuracy is for all samples to be collected from the correct locations at the correct time, placed in a correctly labeled container with the correct preservative, and sealed with custody tape to prevent tampering. Any deviations from these requirements must be documented and explained, and the related data qualified accordingly. During the Bomblet Pit and Five Points Landfill sampling project, all field accuracy goals were met.

\subsubsection{Representativeness}

Representativeness expresses the degree to which sample data accurately and precisely represent a characteristic of a population, parameter variations at a sampling point, or an environmental condition (EPA, 1987). Sample representativeness is achieved through the implementation of a sampling program designed to ensure proper sampling locations, the number of samples, and the use of validated analytical methods. Representativeness may also be assessed through analysis of duplicate samples.

The Bomblet Pit and Five Points Landfill sampling event identified the COCs present in the soils encountered and accurately and precisely quantified their concentrations. Samples were collected from predetermined locations; collection and analysis were performed in accordance with approved procedures, and both field and laboratory duplicates were analyzed. As a result, the sampling data may be qualified as acceptably representative of site-specific environmental conditions. Additional information on the measurement of representativeness is found in the Bomblet Pit and Five Points Landfill SAFER Plan (DOE, 1996).

\subsubsection{Completeness}

Completeness is defined as a percentage of measurements made that are judged to be valid. A sampling and analytical requirement of 80 percent completeness was established for this project (DOE, 1996). With the exception of the unusable isotopic uranium data, the Bomblet Pit and Five Points Landfill sampling data exhibit a high degree of completeness. The sampling and analytical program was executed in accordance with Field Sampling Instructions (IT, 1996), and the specified sampling locations were used as planned. All specified samples were collected, and all sample containers reached the laboratory intact and properly preserved (if applicable). For all samples, sample temperature was maintained during shipment to the laboratory, and the sample 
chain of custody was maintained during sample storage and/or shipment. Although the completeness objective specifically for isotopic uranium was not met due to matrix interference, the objective was fulfilled by calculation of isotopic uranium concentrations from the gamma spectroscopy results (Appendix A).

\subsubsection{Comparability}

Comparability is a qualitative parameter expressing the confidence with which one data set can be compared to another (EPA, 1987). A standardized sampling approach and analytical methodology are used to achieve data comparability. To ensure comparability, the Bomblet Pit and Five Points Landfill field and laboratory activities were performed and documented in accordance with approved procedures, and all samples were collected as per the SAFER Plan (DOE, 1996). Approved standardized methods and procedures were also used to analyze and report the data (e.g., SW-846) (EPA, 1992). This approach ensures that the data from this project can be compared to other data sets. Based on the minimum comparability requirements specified in the SAFER Plan (DOE, 1996), all requirements were met.

\subsection{Field Deficiencies/Nonconformance}

During the. Bomblet Pit and Five Points Landfill field sampling activities, one health and safety surveillance was conducted by the contractor to verify that sampling activities incorporated the applicable health and safety requirements. The results of the surveillance indicated no findings, deficiencies, or nonconformances.

\subsection{Laboratory Nonconformances}

Laboratory nonconformances are generally due to inconsistencies in analytical instrumentation operation and fluctuations in internal standard and calibration results. Several laboratory nonconformances were noted during analysis of the Bomblet Pit and Five Points Landfill samples. These nonconformances are listed below:

- All Five Points Landfill samples for radiological analyses had an ether extraction performed to remove possible iron interference. This required an intentional modification of the standard operating procedure with quality assurance and technical approval.

- Uranium-234 and -238 laboratory control sample recoveries were double the expected value and were, therefore, outside the control limit charts. This resulted in a lower overall accuracy value for the isotopic uranium quality control sample results. 
- The Laboratory Control Samples for two extraction batches (TTR00038 and TTR00046) had no recovery of pyridine. However, because all pyridine results were nondetect, data quality was not impacted.

The noted nonconformances did not affect the overall quality of the sampling event results. Laboratory and validation data qualifiers were assigned, as applicable, to identify those isolated samples (i.e., isotopic uranium and pyridine) that may have had the data quality impacted. The laboratory data packages, which detail nonconformances, are maintained in the project files. 


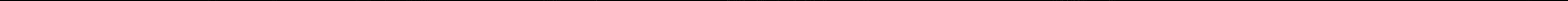




\subsection{Summary}

Analysis of the data generated from sampling activities conducted during verification activities at the Bomblet Pit and Five Points Landfill sites indicates the following:

- Cadmium concentrations were detected above CRDLs in samples collected from Stockpiles \#1 and \#2, the Bomblet Pit, and the Bomblet Processing Area \#2; however, the concentrations are not above the closure standard for cadmium.

- One sample from the Large UXO Processing and Scrap Storage Area detected lead above the CRDL for lead. This concentration is not above the closure standard for lead.

- No other TCLP metals were detected in the samples. The DQOs assumed metal concentrations to be elevated due to components of the explosives used during VCA activities.

- Semivolatile organics were not detected above CRDLs in any of the samples collected from the Bomblet Pit site.

- RDX concentrations were detected above CRDLs; however, the concentrations were not above the closure standard. RDX is a main constituent of the explosives used during VCA activities.

- Radionuclide concentrations from the samples collected from the landfill are almost all at or below background concentrations.

- Isotopic uranium results were deemed unusable due to low recovery of the tracers (matrix spikes) added to the soil samples. Although uranium-238 is not a gamma emitter, several of its decay products are gamma emitters. By performing calculations on the gamma spectroscopy results, it was possible to determine a range that the concentrations of uranium-238 may be found in the soil at Five Points Landfill. The maximum probable uranium-238 concentration ranged from 7.2 to $18.7 \mathrm{pCi} / \mathrm{g}$. The most probable concentration for uranium-238 in the soil at Five Points Landfill is in the range of 1.1 to $4.4 \mathrm{pCi} / \mathrm{g}$. The range of uranium -238 concentration in soil is orders of magnitude less than the guideline concentration of $500 \mathrm{pCi} / \mathrm{g}$. The results demonstrate that the environmental remediation activities at the Five Points Landfill were successful in reducing the uranium- 238 concentrations to less than the guideline concentration and to concentrations not significantly greater than background. 
- Anomalous plutonium-239/240 concentrations were detected in one site characterization sample from the Five Points Landfill (Sample No. TTR00072) and one background sample (No. TTR00065) collected from the Five Points Landfill Background Sample Area. The plutonium-239/240 concentrations were anomalously higher than the other samples from the landfill and the background sample area, but still well below concentrations from background samples collected from other areas on the Nevada Test Site and TTR.

- All other sample results for Isotopic Plutonium are not significantly different than background levels.

The.EPA Equation 8, a statistical method found in Chapter 9 of SW-846 (Test Methods for Evaluating Solid Waste, Physical/Chemical Methods [EPA, 1992]), was applied to all parameters detected above the CRDLs. It was determined that the number of samples collected was in . excess of that required to obtain the required upper confidence limit of 90 percent. This means that the appropriate number of samples was collected and analyzed to accurately verify that constituents of concern are not present above Closure Standards. 


\subsection{Conclusion}

Analytical results indicate that residual contamination from VCA activities conducted at the two sites does not exist. Remedial activities performed at the Five Points Landfill during VCA activities proved to be successful. Based on the process knowledge of the Bomblet Pit and Five Points Landfill, results of remedial actions taken during VCA activities at the two sites, and analytical results, it is recommended that the two sites be clean closed according to NDEP regulations, without further assessment or remediation. Upon notice of completion from NDEP, the sites will be restored and revegetated as specified in Section 3.7 of the SAFER Plan (DOE, 1996). 


\subsection{References}

APHA, see American Public Health Association.

American Public Health Association. 1992. Gross Alpha and Gross Beta Radioactivity, Standard Methods for the Examination of Water and Waste Water, 18th Edition. Washington, DC.

CFR, see Code of Federal Regulations.

Code of Federal Regulations. 1993. 40 CFR §261.24."Toxicity Characteristic." Washington, DC: U.S. Government Printing Office.

Deshler, B. IT Corporation. 1996. Telecon with Art Gravenstein, State of Nevada, about RCRA Subpart S Values, 3 January.

DOE, see U.S. Department of Energy.

EPA, see U.S. Environmental Protection Agency.

IT, see IT Corporation.

IT Corporation. 1996. Field Sampling Instructions for Soil Sampling and Remediation at the Bomblet Pit and Five Points Landfill, Tonopah Test Range, ITLV/10972-163.

Las Vegas, NV.

National Academy of Sciences. 1962. Nuclear Science Series.

National Academy of Sciences. 1963. Nuclear Science Series.

U.S. Department of Energy. 1992. Environmental Measurements Laboratory Procedures Manual, HASL-300, 27th Edition, Volume 1. New York, NY.

U.S. Department of Energy. 1995. Voluntary Corrective Action Work Plan for Ordnance Removal from Five Disposal Sites at the Tonopah Test Range, DOE/NV--386, UC-700. Las Vegas, NV.

U.S. Department of Energy. 1996. Streamlined Approach for Environmental Restoration Plan, CAU No. 400: Bomblet Pit and Five Points Landfill, Tonopah Test Range, DOE/NV--424. Las Vegas, NV. 
U.S. Environmental Protection Agency. 1987. Data Quality Objectives for Remedial Response Activities, EPA/540/G-87-003. Washington, DC.

U.S. Environmental Protection Agency. 1992. Test Methods for Evaluating Solid Waste, Physical/Chemical Methods, SW-846, 3rd Edition, PB89-148076. Washington, DC.

U.S. Environmental Protection Agency. 1994. Guidance for the Data Quality Objectives Process, EPA QA/G-4. Washington, DC.

U.S. Environmental Protection Agency. 1996. Memorandum from Stanford J. Smucker, $\mathrm{PhD}$, to PRG Table Mailing List, "Region 9 Preliminary Remediation Goals (PRGs) 1996," 1 August. 


\section{Appendix A \\ U-238 Concentration in Soil at the Five Points Landfill, Tonopah Test Range}


To:

Richard A. Dubiskas

From: Steven R. Adams SRQ Project No. 764037.07010100

Date:

September 18, 1996

An analysis has been performed to determine whether the concentration of ${ }^{238} \mathrm{U}$ in soil samples taken from the Five Points Landfill could be calculated from gamma spectroscopy analysis and whether its concentration is less than the guideline concentration of $500 \mathrm{pCi} / \mathrm{g}$. The guideline concentration was calculated based upon the public dose limit defined in Department of Energy Order 5400.5 (DOE, 1993).

Analysis of the gamma spectroscopy data confirms that they are adequate for determining the concentration of ${ }^{238} \mathrm{U}$ in the Five Points Landfill soil samples. The most likely concentration of the ${ }^{238} \mathrm{U}$ in the soil is 1 to $4.4 \mathrm{pCi} / \mathrm{g}$. This concentration is typical of background concentrations in soils found on and in the vicinity of the Nevada Test Site. The maximum probable concentration of ${ }^{238} \mathrm{U}$ in soil is less than $18.7 \mathrm{pCi} / \mathrm{g}$. The probability that the ${ }^{238} \mathrm{U}$ concentration exceeds $18.7 \mathrm{pCi} / \mathrm{g}$ is less than 1 in $1,000,000$, or less than $10^{-6}=$ It can safely be assumed that the ${ }^{238} \mathrm{U}$ concentration in the soil samples taken from the Five Points Landfill is orders of magnitude less than the guideline concentration of $500 \mathrm{pCi} / \mathrm{g}$.

Gamma spectroscopy is highly recommended as the analytical method of choice when analyzing soil samples for uranium concentration whenever the decision criteria for ${ }^{238} \mathrm{U}$ exceeds $35 \mathrm{pCi} / \mathrm{g}$. Typical background concentration for ${ }^{238} \mathrm{U}$ in soil on and in the vicinity of the Nevada Test Site is 0.3 to $3.0 \mathrm{pCi} / \mathrm{g}$ (Adams, 1996b). Gamma spectroscopy is capable of detecting the gamma-emitting decay products of ${ }^{238} \mathrm{U}$ at concentrations significantly below $35 \mathrm{pCi} / \mathrm{g}$. Detection of $\mathrm{U}^{238}$ decay products at low concentrations ensures high reliability for detecting $\mathrm{U}^{238}$ in soil samples. Gamma spectroscopy offers several advantages in comparison to alpha spectroscopy for detecting $\mathrm{U}^{238}$ in soil samples at guideline concentrations. For example, it is faster. Turn-around time for gamma spectroscopy is two to four days while alpha spectroscopy takes one to three weeks. Secondly, gamma spectroscopy is cheaper. Gamma spectroscopy costs about $\$ 50$ per sample while alpha 
spectroscopy is cheaper. Gamma spectroscopy costs about $\$ 50$ per sample while alpha spectroscopy costs about $\$ 400$ per sample. In addition, alpha spectroscopy requires extensive sample preparation, including significant wet chemistry processes. The sample preparation process presents opportunities for procedural errors and interference from soil constituents, resulting in incorrect analytical outcomes. Gamma spectroscopy requires a minimum of sample preparation and no wet chemistry requirements.

\section{Introduction}

The Five Points Landfill was used to temporarily store waste from road construction and ordinance testing from operations occurring during the early 1970s (Dubiskas, 1996). The ordinance is manufactured using depleted uranium. Depleted uranium is 99.75 percent ${ }^{238} \mathrm{U}$ by mass, and 89.4 percent of the radioactivity is due to the ${ }^{238} \mathrm{U}$ (Rich, 1988). Environmental restoration activities have been performed at the Five Points Landfill, and guideline concentrations for ${ }^{238} \mathrm{U}$ contamination in soil have been established. The guideline concentration is calculated based upon the public dose limit defined in DOE Order 5400.5 (DOE, 1993). The guideline concentration is a radionuclide concentration in soil that, given appropriate use scenarios and site parameters, will reasonably ensure that individual dose limits of 100 mrem/year will not be exceeded. The guideline concentration calculated for ${ }^{238} \mathrm{U}$ at the Five Points Landfill is $500 \mathrm{pCi} / \mathrm{g}$ (Adams, 1996a). Soil samples have been taken and analyzed to demonstrate that the guideline concentration has been attained.

Fifteen soil samples from the Five Points Eandfill were analyzed for ${ }^{238} \mathrm{U}$ using alpha spectroscopy. Relatively high concentrations of natural metals in the soil (e.g., iron) interfered with the standard laboratory procedures used in processing the soil samples for alpha spectroscopy. This interference resulted in unacceptably low yields for the uranium tracer added to the soil samples. The low yields, less than three percent, were not adequate to ensure sufficient quality in the alpha spectroscopy results. However, gamma spectroscopy was also performed on the soil samples, and the data quality was acceptable. Although ${ }^{238} \mathrm{U}$ is not a gamma emitter, several of its decay products are gamma emitters. Because the decay products are in secular equilibrium with ${ }^{238} \mathrm{U}$, their concentration in the soil is essentially the same as that of ${ }^{238} \mathrm{U}$. The concentration of the decay products can, therefore, be accepted as analogs for the concentration of ${ }^{238} \mathrm{U}$ in soil. The use of gamma spectroscopy is recommended when the guideline ${ }^{238} \mathrm{U}$ concentration is significantly above the natural background concentration of ${ }^{238} \mathrm{U}$, 
which is in the range of 0.3 to $3 \mathrm{pCi} / \mathrm{g}$ (Adams, 1996b). Since the background concentration of ${ }^{238} \mathrm{U}$ is orders of magnitude less than the guidance concentration, the interference from background concentration of ${ }^{238} \mathrm{U}$ is zero.

\section{Analysis}

The decay scheme of ${ }^{238} \mathrm{U}$ is complex and includes eight alpha-emitting decay products and nine beta-emitting decay products. An illustration of the ${ }^{238} \mathrm{U}$ decay scheme is shown in Figure 1.

This figure is from Table 8.9 of the Health Physics and Radiological Health Handbook (Shleien, 1992). The half-life of ${ }^{238} \mathrm{U}$ is very long, $4.468 \times 10^{9}$ years. The half-lives of the ${ }^{238} \mathrm{U}$ decay products are many orders of magnitude less. The decay product with the longest half-life is ${ }^{234} \mathrm{U}$, which has a half-life of 244,500 years. If a parent radionuclide is present and has a very long half-life while the radioactive decay product has a relatively short half-life, a condition of radioactivity equilibrium will be reached for all practical purposes after a period of six half-lives of the decay product. At that time, the radioactivity of the short-lived decay product will have been built up to a maximum value. The radioactivity of the short-lived decay product will then be in equilibrium with the radioactivity of the long-lived parent so that, on the average, disintegration of the parent will be accompanied by a disintegration of the decay product. This type of equilibrium is called secular equilibrium. Figure 2 shows how the radioactivity of the decay product builds up to the radioactivity of the parent radionuclide under the conditions of secular equilibrium. For ${ }^{238} \mathrm{U}$ the first three decay products, ${ }^{234} \mathrm{Th},{ }^{234 \mathrm{~m}} \mathrm{~Pa}$, and ${ }^{234} \mathrm{~Pa}$, are in secular equilibrium within eight days of the processing of the depleted uranium. A mathematical description for secular equilibrium can be found in any standard nuclear physics textbook, (e.g.; Evans, 1955). A mathematical development for secular equilibrium along with a calculation . demonstrating that the ${ }^{238} \mathrm{U}$ decay chain through ${ }^{234} \mathrm{~Pa}$ is in secular equilibrium with the ${ }^{238} \mathrm{U}$ is included with this memorandum in Attachment 1.

The first three decay products of ${ }^{238} \mathrm{U},{ }^{234} \mathrm{Th},{ }^{234 \mathrm{mPa}} \mathrm{P}$ and ${ }^{234} \mathrm{~Pa}$, are in secular equilibrium with the ${ }^{238} \mathrm{U}$ concentration in soil. As shown in Figure 1, the gamma emissions from the ${ }^{234} \mathrm{Th},{ }^{234 \mathrm{mma}}$ and ${ }^{234} \mathrm{~Pa}$ are either low in energy or intensity. None of the gammas are emitted with an intensity exceeding 12 percent. That is, during a disintegration, the most common gamma energy emitted, the 0.946 million electron volts $(\mathrm{MeV})$ gamma emitted from ${ }^{234} \mathrm{~Pa}$, is emitted only 12 percent of the time. All of the emissions from ${ }^{234} \mathrm{Th}$ and ${ }^{234 \mathrm{~m}} \mathrm{~Pa}$ are very low energy, less than $0.1 \mathrm{MeV}$, or of very low intensity, less than 1 percent. Detection of these isotopes at concentrations near 
CAU No. 400: Bomblet

Pit and Five Points Landfill

Section: Appendix A

Revision: 1

Date: $11 / 22 / 96$

Page 47 of 58

FIGURE 1 238 U DECAY SCHEME

RadionUclide Data

283

Table 8.9 Uranium Series $(4 n+2)^{\mathrm{a}}$

(Personal communication L. Slaback after Kocher 1981 and ICRP Report No. 3S, 19S3. In case of discrepancy, ICRP value given)

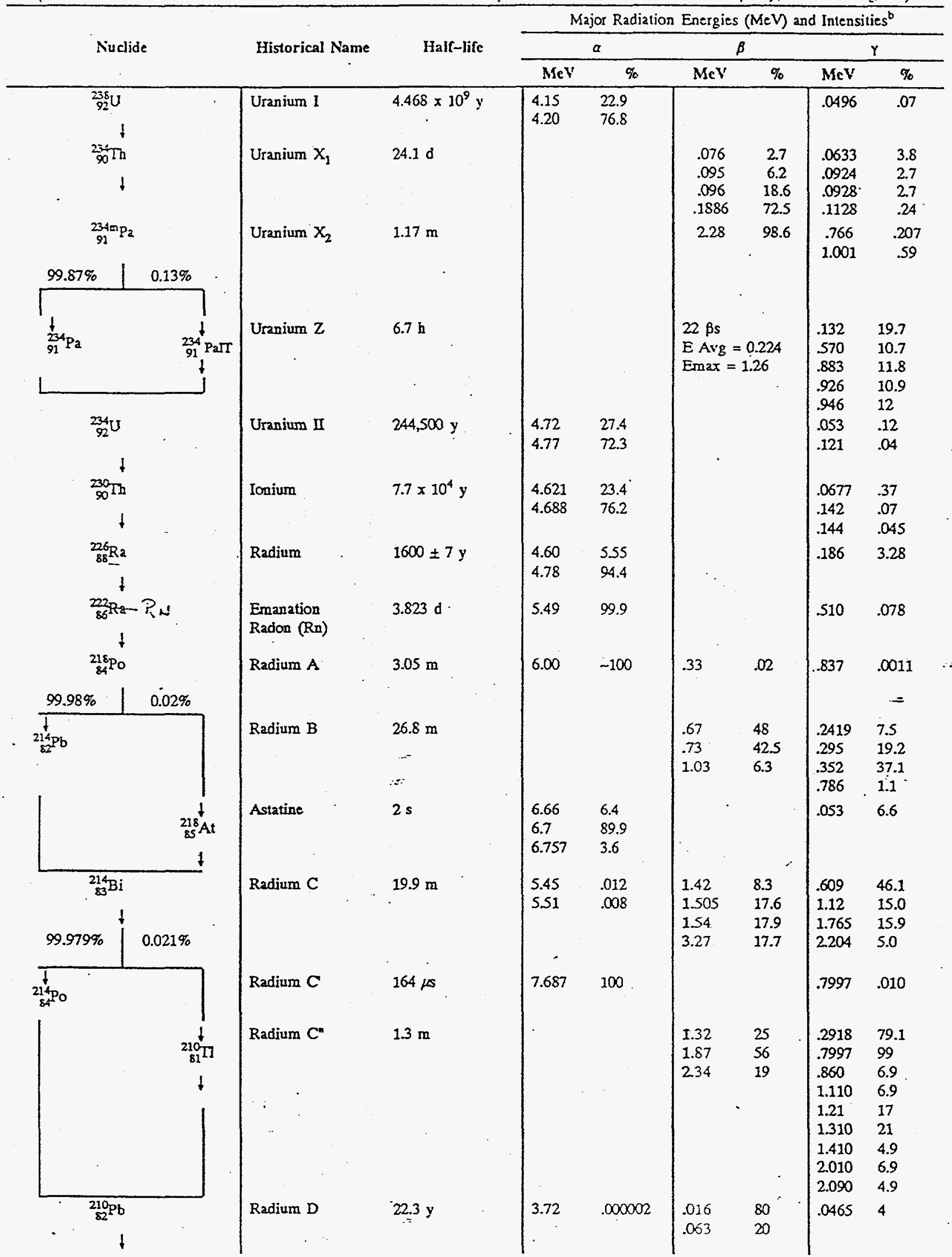


CAU No. 400: Bomblet Pit and Five Points Landfill Section: Appendix A

Revision: 1

Date: $11 / 22 / 96$

Page 48 of 58

284 The Health PHysics and Radiological Healith HaNdBoOK

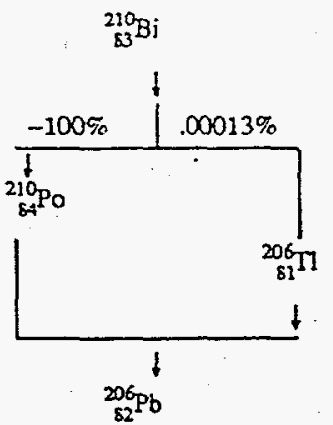

Radium E

$5.01 \mathrm{~d}$

.00007

1.161

$-100$

Radium $F$

$135.378 d$

Radium $E^{n}$

$4.20 \mathrm{~m}$

Radium G

stable

2 This expression describes the mass number of any member in this series, where $n$ is an integer. For example: ${ }^{206} \mathrm{~Pb}(4 \mathrm{n}+2) \ldots 4(51)+2=206$

b Intensities refer to percentage of disintegrations of the nuclide itself, not to original parent of series. Gamma \%os: in tems of observable emissions, not transitions. 
CAU No. 400: Bomblet

$P$ it and Five Points Landfill

Section: Appendix A

Revision: 1

芯

Date: 11/22/96

ते ले

Page 49 of 58

正

13

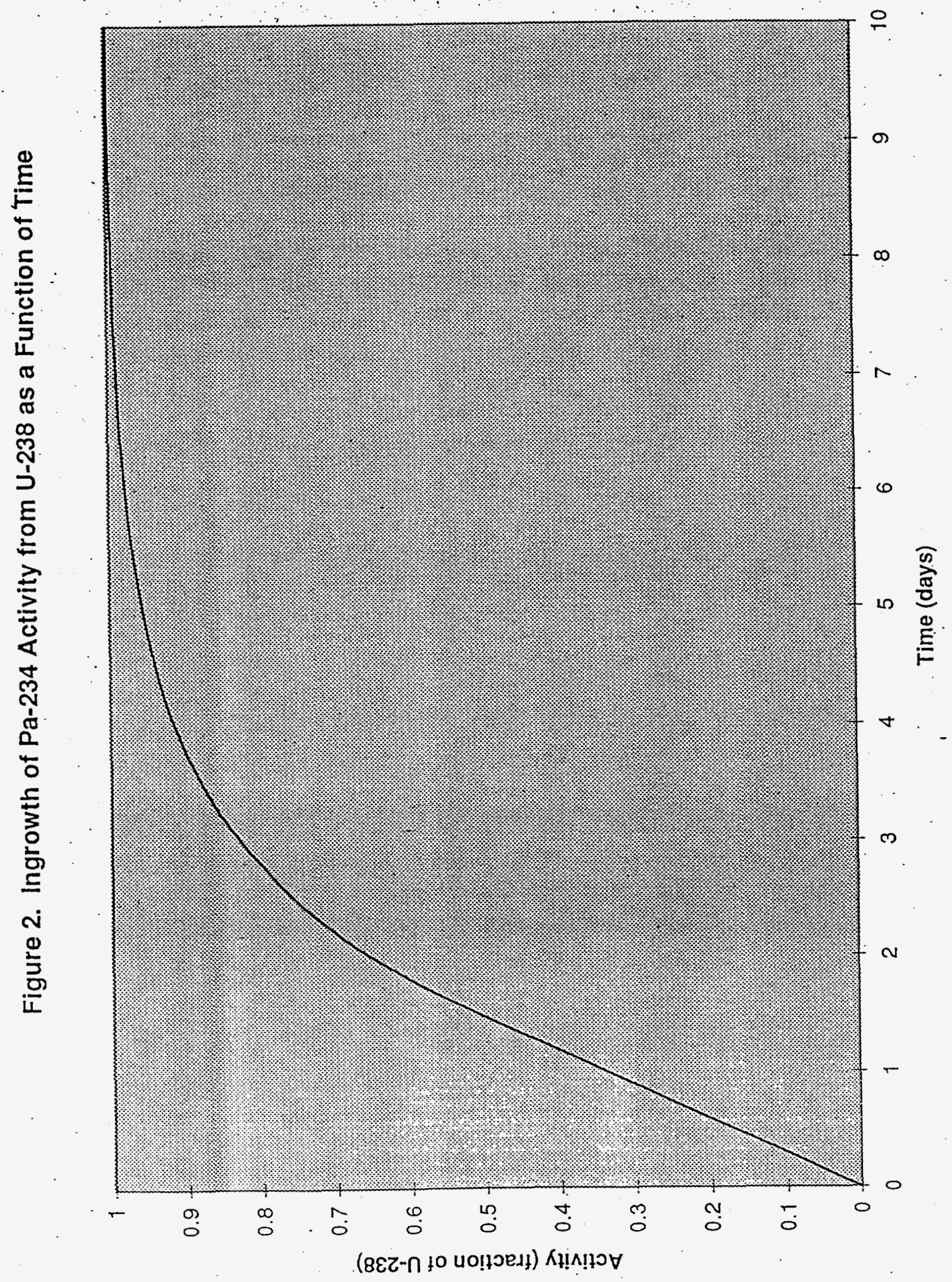


environmental background concentration is challenging using gamma spectroscopy. Often the minimum detectable concentration for a radionuclide in soil that can be attained by an analytical laboratory is greater than background concentration. The laboratory used for analyzing the Five Points Landfill soil samples reports the minimum detectable concentration (MDC) for each radionuclide detected for each sample. Under these circumstances, the $\mathrm{MDC}$ for ${ }^{234} \mathrm{Th}$ and ${ }^{234} \mathrm{~Pa}$ is used to determine the ${ }^{238} \mathrm{U}$ concentration in the sample.

Radioactive decay is a random process. .Consequently, any measurement which is based on observing the radiation emitted in nuclear decay is subject to some degree of statistical fluctuation. These inherent fluctuations represent an unavoidable source of uncertainty in all nuclear measurements, and they can often can be the predominant source of imprecision or error. The term "counting statistics" includes the framework of statistical analysis required to process the results of nuclear counting measurements, for example, the number of photons of a specific energy emitted from a soil sample. Counting statistics can be applied to making predictions about the expected precision of quantities derived from nuclear counting measurements, such as determining the concentration of a radionuclide in a soil sample.

Counting statistics are used to predict the inherent statistical uncertainty and thus estimate a precision that should be associated with a single measurement. The counting statistic appropriate to describe gamma interactions in solid state spectroscopy detectors is the Gaussian distribution (Knoll, 1979). The Gaussian distribution has the following properties:

- The distribution is symmetric about the mean value. Therefore, the probability of success for a specific event $P(x)$ depends only on the absolute value of the deviation of any value $\mathrm{x}$ from the mean.

- Because the mean value is large, values of $P(x)$ for adjacent values of $x$ are not greatly different from each other. In other words, the distribution is slowly varying.

- The distribution is characterized by a single parameter, the mean, which is given by the product $n p$, where $n$ is the number of events and $p$ is the probability of success for a specific event. 
- The predicted variance is equal to the mean value of the distribution, and the standard deviation is equal to the square root of the mean value of the distribution.

The Gaussian distribution can be described as an explicit, continuous function of the deviation $\epsilon$ and the variance $\sigma^{2}$ rather than $\mathrm{x}$ :

$$
G(\epsilon)=\left(2 / \pi \sigma^{2}\right)^{1 / 2} \times \exp \left(-\epsilon^{2} / 2 \sigma^{2}\right)
$$

where

$G(\epsilon)=$ Gaussian distribution with respect to the deviation $\epsilon$;

$\pi=$ pi, the ratio between the circumference and diameter of a circle;

$\sigma^{2}=$ the variance of the Gaussian distribution; and

$\exp =$ the exponential function where the value $\mathrm{e}$ is raised to the power expressed in the parentheses.

From the definition of the Gaussian distribution, the probability that a typical deviation $\epsilon$ predicted by a Gaussian distribution will be less than a specific value $\epsilon_{(0)}$ is given by the integral:

$$
\int_{0}^{\epsilon_{0}} G(\epsilon) d \epsilon \equiv f\left(\epsilon_{0}\right)
$$

Provided $\epsilon_{(0)}$ is chosen in units of the standard deviation, $\sigma, f\left(\epsilon_{0}\right)$ becomes independent of all other parameters of the distribution and will be a universal property of all Gaussian distributions. Tabular values for $\mathrm{f}\left(\epsilon_{0}\right)$ can be found in most collections of statistical tables; and some selected entries have been calculated and are listed below.

\section{Probability of Occurrence of Given Deviations}

\section{Predicted by the Gaussian Distribution}

$\begin{array}{lc}\epsilon_{0} & \frac{f\left(\epsilon_{0}\right)}{0} \\ 0 & 0 \\ 0.674 \sigma & 0.500 \\ 1 \sigma & 0.683 \\ 1.64 \sigma & 0.900\end{array}$




$\begin{array}{ll}\epsilon_{0} & f\left(\epsilon_{0}\right) \\ 1.96 \sigma & 0.950 \\ 2.58 \sigma & 0.990 \\ 3.00 \sigma & 0.997 \\ 5.00 \sigma & 0.99999968\end{array}$

The function $\mathrm{f}\left(\epsilon_{0}\right)$ gives the probability that a random sample from a Gaussian distribution will show a deviation from the true mean value that is less than the assumed value of $\epsilon_{0}$. For example, we can conclude that 68.3 percent of all samples will deviate from the true mean by less than one value of the standard deviation, while less than 0.0001 percent of all samples will deviate from the true mean by less than five standard deviations. Thus, if a value is chosen that is greater than five standard deviations from the true mean, the probability of it occurring is less than 0.0001 percent or less than $10^{-6}$.

This property of the Gaussian distribution is used in determining the maximum probable concentration of the ${ }^{238} \mathrm{U}$ in a soil sample. As stated previously, the standard deviation of a Gaussian distribution is equal to the square root of the mean. The concentration of a radionuclide in a soil sample, as determined by radioanalysis, is the mean value of the Gaussian distribution of possible concentrations. Therefore, the concentration of a radionuclide in a soil sample is also a good approximation of the variance for the Gaussian distribution of possible = radionuclide concentrations in a soil sample. The probability that the concentration of a radionuclide that is $5 \sigma$ higher than the mean value for that radionuclide is truly representative of the radionuclide's concentration is less than $10^{-6}$. For example, if the analytical results show a concentration of $9 \pm 4.5 \mathrm{pCi} / \mathrm{g}$, then the mean of the Gaussian distribution is $9 \mathrm{pCi} / \mathrm{g}$, and 4.5 $\mathrm{pCi} / \mathrm{g}$, which is two standard deviations of the mean, represents the 95 percent confidence value about the mean. Thus, there is a 95 percent confidence that the true value is within $9 \pm 4.5 \mathrm{pCi} / \mathrm{g}$ $(4.5$ to $13.5 \mathrm{pCi} / \mathrm{g})$.

The gamma spectroscopy results for the Five Points Landfill soil samples list the radionuclide concentration with two standard deviations of the concentration. When the concentration of the radionuclide is less than the minimum detectable concentration, then the MDC is listed. Only six of the 45 measurements of the three radionuclides in secular equilibrium with the ${ }^{238} \mathrm{U}$ have means exceeding two standard deviations. The other 39 measurement results list the MDC. 
When the MDC is listed, the maximum probable ${ }^{238} \mathrm{U}$ is defined as that concentration that is $5 \sigma$ greater than the MDC. Recall from the previous discussion on the Gaussian distribution that the standard deviation $\sigma$ is equal to the square root of the mean. For example, if the ${ }^{234} \mathrm{Th} \mathrm{MDC}$ is 4 $\mathrm{pCi} / \mathrm{g}$ then the maximum probable concentration of ${ }^{238} \mathrm{U}$ in the soil is equal to $14 \mathrm{pCi} / \mathrm{g}$, i.e., $4+5 \sigma=4+5(\sqrt{4})$. For the six measurements at this site in which the mean concentration exceeds two standard deviations, the actual standard deviation will be used to determine the maximum probable concentration of the ${ }^{238} \mathrm{U}$. For example, when the ${ }^{234} \mathrm{Th}$ concentration is $9 \pm$ $5.2 \mathrm{pCi} / \mathrm{g}$, then the maximum probable ${ }^{238} \mathrm{U}$ concentration is defined as $22 \mathrm{pCi} / \mathrm{g}(9+5(5.2 / 2))$.

\section{Conclusions}

The results of the analysis of the gamma spectroscopy of the Five Points Landfill soil samples are listed in Table 1. The concentration or MDC of the three radionuclides in secular equilibrium with ${ }^{238} \mathrm{U}$ is listed along with the concentration of other radionuclides in the ${ }^{238} \mathrm{U}$ decay chain that decay prior to the ${ }^{222} \mathrm{Rn}$ gas. The maximum probable ${ }^{238} \mathrm{U}$ concentration is listed based upon the methodology discussed in the previous section. The results demonstrate that the maximum probable concentration of the ${ }^{238} \mathrm{U}$ concentration ranged from 7.2 to $18.7 \mathrm{pCi} / \mathrm{g}$. The probability that the ${ }^{238} \mathrm{U}$ concentration in soil exceeds a value in this range is less than $10^{-6}$. The range of ${ }^{238} \mathrm{U}$ concentration in soil is orders of magnitude less than the guideline concentration of $500 \mathrm{pCi} / \mathrm{g}$.

The most probable concentration for ${ }^{238} \mathrm{U}$ in the soil sample is in the range of 1.1 to $4.4 \mathrm{pCi} / \mathrm{g}$; This is the range of the six measurements that exceeded the MDC by at least two standard deviations. This is not significantly different from background concentrations for ${ }^{238} U$ of 0.3 to 3 $\mathrm{pCi}$.

Gamma spectroscopy analysis has been successfully used in determining that the ${ }^{238} \mathrm{U}$ concentration in Five Points Landfill soil samples does not exceed the guideline concentration of $500 \mathrm{pCi} / \mathrm{g}$. Based upon the gamma spectroscopy analysis of the 15 soil samples, the ${ }^{238} \mathrm{U}$ concentration in soil is not significantly different from background. The results demonstrate that the environmental remediation activities at the Five Points Landfill was successful in reducing the ${ }^{238} \mathrm{U}$ concentration to orders of magnitude less than the guideline concentration and to concentrations not significantly greater than background. 
CAU No. 400: Bomblet

Pit and Five Points Landfill

Section: Appendix A

Revision: 1

Date: $11 / 22 / 96$

Page 54 of 58

R. Dubiskas

September 18, 1996

It is recommended that gamma spectroscopy be used to determine the concentration of ${ }^{238} U$ in soil samples when guideline concentrations exceed $35 \mathrm{pCi} / \mathrm{g}$. The use of gamma spectroscopy will reduce turn-over time in obtaining laboratory results and significantly reduce the cost per sample. 
Table 1 Maximum ${ }^{238} U$ Concentration in Five Points Landfill Soil Samples $\begin{aligned} & \text { Date: } 11122196 \\ & \text { Page } 55 \text { of } 58\end{aligned}$ $(p \mathrm{Ci} / \mathrm{g})$

\begin{tabular}{|c|c|c|c|c|c|c|}
\hline Sample iD & $\begin{array}{ccc}\cdots & \text { Analy } \\
& & \end{array}$ & cal Results & ${ }^{228} \mathrm{Ra}$ & ${ }^{214} \mathrm{~Pb}$ & ${ }^{210} \mathrm{~Pb}$ & $\begin{array}{c}\text { Maximum } \\
\text { Probable } \\
238 \mathrm{U}^{\text {(a) }}\end{array}$ \\
\hline $001^{(b)}$ & $5.094 \mathrm{MDC}^{(\mathrm{c})}$ & $0.882 \mathrm{MDC}$ & 6.398 MDC & $.2 .369 \pm .6569$ & not reported & 7.2 \\
\hline 002 & $2.336 \mathrm{MDC}$ & $0.4241 \mathrm{MDC}$ & $3.855 \mathrm{MDC}$ & $1.499 \pm .5463$ & not reported & 13.7 \\
\hline 003 & $1.067 \pm 1.191$ & $0.3589 \mathrm{MDC}$ & $2.654 \mathrm{MDC}$ & $1.315 \pm .3077$ & $2.561 \pm 1.78$ & 10.8 \\
\hline 004. & $4.334 \mathrm{MDC}$ & $0.5935 \mathrm{MDC}$ & 4.114 MDC & $0.907 \pm .3854$ & not reported & 14.7 \\
\hline $005^{\circ}$ & $2.223 \pm 1.289$ & 0.4657 MDC & $3.056 \pm 2.789$ & $1.026 \pm .2972$ & $2.098 \pm 1.629$ & 10.0 \\
\hline 006 & $5.25 \mathrm{MDC}$ & $0.8642 \mathrm{MDC}$ & $6.142 \mathrm{MDC}$ & $1.015 \mathrm{MDA}$ & $63.15 \mathrm{MDA}$ & 18.5 \\
\hline 0.07 & $2.269 \mathrm{MDC}$ & $0.415 \mathrm{MDC}$ & $3.861 \mathrm{MDC}$ & $0.6199 \mathrm{MDA}$ & 2.394 MDA & 13.7 \\
\hline 008 & $0.9385 \pm 1.369$ & $0.355 \mathrm{MDC}$ & $3.54 \pm 2.445$ & $1.262 \pm .3162$ & $2.082 \pm 2.022$ & 9.65 \\
\hline 009 & 4.458 MDC & $0.6136 \mathrm{MDC}$ & $6.875 \mathrm{MDC}$ & $1.17 \pm .3775$ & $29.24 \mathrm{MDA}$ & 20 \\
\hline .010 & $2.314 \mathrm{MDC}$ & $0.4433 \mathrm{MDC}$ & $3.588 \pm 4.038$ & $1.339 \pm .3573$ & not reported & 13.7 \\
\hline 011 & $5.292 \mathrm{MDC}$ & 0.9393 MDC & $6.228 \mathrm{MDC}$ & $0.8888 \mathrm{MDA}$ & $5.447 \pm 33.31$ & 18.7 \\
\hline 012 & No Results & $0.4606 \mathrm{MDC}$ & $4.104 \mathrm{MDC}$ & not reported & not reported & 14.2 \\
\hline 013 & $3.362 \pm 1.387$ & $0.3997 \mathrm{MDC}$ & $4.429 \pm 2.869$ & $1.226 \pm .3277$ & not reported & 15 \\
\hline 013DUP & 4.994 MDC & $0.6354 \mathrm{MDC}$ & $2.87 \pm 3.779$ & $1.415 \pm .3529$ & not reported & 16.2 \\
\hline 014 & $2.268 \mathrm{MDC}$ & $0.4184 \mathrm{MDC}$ & $3.054 \pm 2.879$ & $621 \pm .3847$ & ${ }^{10} \mathrm{~Pb}=2.91 \pm 1.981$ & 10.3 \\
\hline
\end{tabular}

(a) The maximum probable $U-238$ concentration = mean plus 5 standard deviations of the mean

(b) Sample ID is the the last 3 digits of the laboratory ID, 11426-001 is recorded as 001 .

(c) MDC is Quanterra laboratory calculated minimum detectable concentration 


\section{References}

DOE See U.S. Department of Energy

Adams, S. R. 1996a. Five Points Landfill Cleanup Level. Memorandum from S. R. Adams, IT Las Vegas, to Karen Beckley, Nevada Division of Environmental Protection, June 18. Adams, S. R. 1996b. Interoffice memorandum to Ed Thomas about the Concentration of Gross Alpha and Beta Emitters in Background Soil in the Vicinity of the NTS. May 29.

Dameran, S. 1972. Nuclear Radiation Physics, 4th edition. Lapp and Andrews.

Dubiskas, R.A. 1996. Personal Communication to S. R. Adams, January 2.

Evans, R. D. 1955. The Atomic Nucleus. New York, NY: McGraw-Hill.

Fitzgerald, J. J. et al., 1967. Mathematical Theory of Radiation Dosimetry. New York, NY: Gordon and Breach.

Johns, H. E., and J.R. Cunningham. 1974. The Physics of Radiology, 3rd Edition. Springfield, IL: Charles C. Thomas.

Knoll, G. F. 1979. Radiation Detection and Measurements. New York, NY: John Wiley \& Sons, Inc.

Rich, B.L. et al., 1988. Health Physics Manual of Good Practices for Uranium Facilities. EGG2530. Idaho Falls, ID: EG\&G Idaho.

Shleien, B. (Ed.) 1992. The Health Physics and Radiological Health Handbook. Silver Springs,MD: Scinta, Inc.:

U.S. Department of Energy, 1993. DOE Order 5400.5 change 2. Radiation Protection of the : Public and the Environment. Washington DC. 
CAU No. 400: Bomblet

$P$ it and Five Points Landfill

Section: Appendix A

Revision: 1

Date: $11 / 22 / 96$

Page 57 of 58

\section{Attachment 1}

Secular Equilibrium for ${ }^{238} \mathrm{U}$ 
Equation 3-19 from The Physics of Radiology (Johns and Cunningham, 1977) can be used to determine the activity of a decay product given the activity of the parent. Given: a radioactive parent $A_{1}$ decays to $A_{2}$ with a half-life of $T_{1}$, and $A_{2}$ decays with a half-life of $T_{2}$ then:

$A_{2}=A_{1}\left[T_{1} /\left(T_{2}-T_{1}\right)\right] \times\left[1-\exp ^{-(0.693[(T 1-T 2) /(T 1 \times T 2)] \times t)}\right]$

where:

$\mathrm{A}_{1}=$ activity of the parent

$\mathrm{A}_{2}=$ activity of the decay product

$\mathrm{T}_{1}=$ half-life of the parent

$\mathrm{T}_{2}=$ half-life of the decay product

$0.693=\quad$ natural $\log$ of 2

$\mathrm{t}=$ time specified time period

Evaluation of equation (1) demonstrates that the exponential term approaches zero when $(t)$ is very long relative to the half life of the daughter. In addition, if $T_{2}<<T_{1}$ then equation (1) can be shown to reducae to $A_{2}=A_{1}$.

One of the natural radioactive uranium decay chain is: $\mathrm{U}-238 \Rightarrow \mathrm{Th}-234 \Rightarrow \mathrm{Pa}-234 \mathrm{~m} \Rightarrow \mathrm{Pa}-234$ As U-238 decays to $\mathrm{Pa}-234$ it can be shown that the half life Th-234 is very short in relation to $\mathrm{U}-238$ and therefore the Th-234 activity is equal to the parent.

For the next decay series Th-234 to $\mathrm{Pa}-234 \mathrm{~m}$ the same situation holds true, where the half life of Th-234 is 24.1 days and the half life of $\mathrm{Pa}-234 \mathrm{~m}$ is 1.17 minutes. Thus activity of $\mathrm{Pa}-234 \mathrm{~m}=$ activity $\mathrm{Th}-234=$ activity $\mathrm{U}-238$.

The activity of the $\mathrm{Pa}-234$, daughter of $\mathrm{Pa}-234 \mathrm{~m}$, can be calculated using equation (2.64) inThe Mathematical Thoery of Radiation (Fitzgerald et al., 1975).

$$
N_{2}=N_{1}\left[\lambda_{1} /\left(\lambda_{2}-\lambda_{1}\right)\right] e^{-\left(\lambda_{1} t\right)}
$$

Equation (2) demonstrates that the daughter will equal the activity of the parent at very short decay times relative to the parent's half -life. For the situation of $\mathrm{Pa}-234 \mathrm{~m}$ going to $\mathrm{Pa}-234$ the parent activity is continuously being added to by the Th-234 therefore, the activity of the Pa-234 will be equal to the activity of the $\mathrm{Pa}-234 \mathrm{~m}$ for all practical purposes. 


\section{Distribution List}

\section{Copies}

Stephen A. Mellington

1 (Uncontrolled)

DOE/Nevada Operations Office

P.O. Box 98518

Las Vegas, NV 89193-8518

Kevin Cabble

2 (Uncontrolled)

DOE/Nevada Operations Office

P.O. Box 98518

Las Vegas, NV 89193-8518

Janet Appenzeller-Wing

1 (Uncontrolled)

DOE/Nevada Operations Office

P.O. Box 98518

Las Vegas, NV 89193-8518

Mr. Paul Liebendorfer

1

State of Nevada

Bureau of Federal Facilities

Division of Environmental Protection

333 W. Nye Lane

Carson City, NV 89710

Ms. Karen Beckley

State of Nevada

Division of Environmental Protection

555 East Washington, Suite 4300

Las Vegas, NV 89101

Environmental Restoration Division Records Center

DOE/Nevada Operations Office

P.O. Box 98518

Las Vegas, NV 89193-8518 